Final Report Presented to the Nisqually Indian Tribe

\title{
Otolith Analysis of Pre-Restoration Habitat Use by Chinook Salmon in the Delta-Flats and Nearshore Regions of the Nisqually River Estuary
}

Open-File Report 2010-1238

Version 1.1, May 2011 



\section{Otolith Analysis of Pre-Restoration Habitat Use by Chinook Salmon in the Delta-Flats and Nearshore Regions of the Nisqually River Estuary}

By Angie Lind-Null and Kim Larsen

Final Report Presented to the Nisqually Indian Tribe

Open-File Report 2010-1238

Version 1.1, May 2011 


\section{U.S. Department of the Interior \\ KEN SALAZAR, Secretary}

\section{U.S. Geological Survey \\ Marcia K. McNutt, Director}

U.S. Geological Survey, Reston, Virginia: 2010

Revised: May 2011

For more information on the USGS-the Federal source for science about the Earth, its natural and living resources, natural hazards, and the environment, visit http://www.usgs.gov or call 1-888-ASK-USGS.

For an overview of USGS information products, including maps, imagery, and publications, visit http://www.usgs.gov/pubprod

To order this and other USGS information products, visit http://store.usgs.gov

Suggested citation:

Lind-Null, Angie, and Larsen, Kim, 2010, Otolith analysis of pre-restoration habitat use by Chinook salmon in the deltaflats and nearshore regions of the Nisqually River Estuary: U.S. Geological Survey Open-File Report 2010-1238, 28 p.

Any use of trade, product, or firm names is for descriptive purposes only and does not imply endorsement by the U.S. Government.

Although this report is in the public domain, permission must be secured from the individual copyright owners to reproduce any copyrighted material contained within this report. 


\section{Contents}

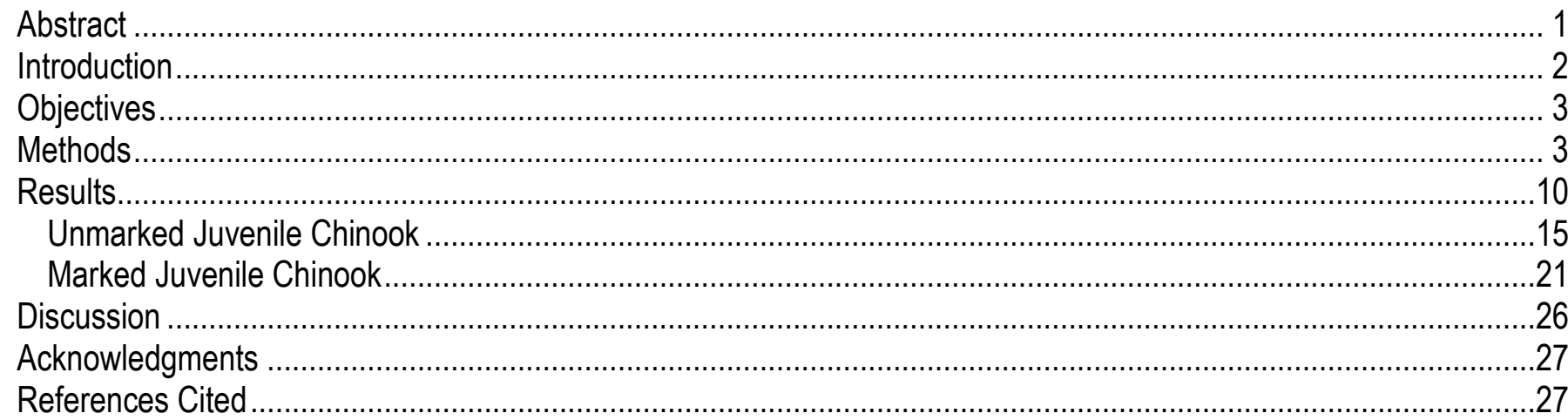

\section{Figures}

Figure 1. Distinct habitat zones of the lower Nisqually River with field sampling sites shown for the nearshore

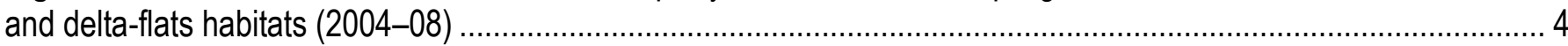

Figure 2. Relationship between fish fork length and otolith radial distance. ......................................................... 9

Figure 3. Representative unmarked and marked otolith samples of freshwater growth in juvenile Chinook salmon collectedfrom Nisqually River Basin, Washington, 2004-08

Figure 4. Mean increment width of the freshwater, tidal delta, and delta-flats/nearshore portions of the otolith for unmarked and marked juvenile Chinook salmon residing in the delta-flats and nearshore habitat zones, Nisqually River Basin, Washington, 2004-08.

Figure 5. Average complete tidal delta growth rate by year for unmarked and marked juvenile Chinook salmon collected from the delta-flats and nearshore habitats, Nisqually River Basin, Washington, 2004-08

Figure 6. Average delta-flats/nearshore growth rate by year for unmarked and marked juvenile Chinook salmon collected from the delta-flats and nearshore habitats, Nisqually River Basin, Washington, 2004-08

Figure 7. Representative otolith sample depicting the tidal delta check as seen on unmarked juvenile Chinook salmon collected in the delta-flats habitat beginning in mid-April 2004-08 and in the nearshore habitat beginning in mid-May 2004-08, Nisqually River Basin, Washington

Figure 8. Representative otolith sample depicting the delta-flats check as seen on unmarked juvenile Chinook salmon collected in the delta-flats habitat beginning in early March 2004-08 and in the nearshore habitat beginning in mid-March 2004-08, Nisqually River Basin, Washington.

Figure 9. Presence or absence of a delta-flats check on unmarked juvenile Chinook salmon collected in the delta-flats and nearshore habitats, Nisqually River Basin, Washington, 2004-08.

Figure 10. Representative otolith sample of fry migrants seen on unmarked juvenile Chinook salmon collected in the delta-flats habitat beginning in early February and the nearshore habitat in mid-March 2005 and 2007-08, Nisqually River Basin, Washington.

Figure 11. Complete tidal delta residence time, separated by year, for individual unmarked juvenile Chinook salmon caught in the delta-flats and nearshore habitats, Nisqually River Basin, Washington, 2004-08 .

Figure 12. Representative otolith sample depicting the tidal delta check as seen on marked juvenile Chinook salmon collected in the delta-flats habitat beginning in mid-May 2004-08 and in the nearshore habitat beginning in early May 2004-08, Nisqually River Basin, Washington.

Figure 13. Representative otolith sample depicting the delta-flats check as seen on marked juvenile Chinook salmon collected in the delta-flats habitat beginning in mid-May 2004-08 and in the nearshore habitat beginning in late May 2004-08, Nisqually River Basin, Washington.....

Figure 14. Presence or absence of a delta-flats check on marked juvenile Chinook salmon collected in the delta-flats and nearshore habitats, Nisqually River Basin, Washington, 2004-08 ..... 
Figure 15. Complete tidal delta residence time, separated by year, for individual marked juvenile Chinook

salmon caught in the delta-flats and nearshore habitats, Nisqually River Basin, Washington, 2004-08 .....

\section{Tables}

Table 1. Number of unmarked and marked juvenile Chinook salmon collected for otolith analysis in the delta-flats (DF) and nearshore (NS) habitats, Nisqually River Basin, Washington, 2004-08 ............................................... 5

Table 2. Number of unmarked hatchery samples separated from the dataset. ....................................................... 6

Table 3. Number of otoliths (one per fish) analyzed/processed ........................................................................ 7

Table 4. Number of otoliths (one per fish) with a tidal delta check (TDCK) or delta-flats check (DFCK).................... 11

Table 5. Average fork length (in millimeters) of unmarked juvenile Chinook salmon at entrance to and exit from the tidal delta, separated by year and habitat type, Nisqually River Basin, Washington, 2004-08.

Table 6. Average fork length (in millimeters) of marked juvenile Chinook salmon at entrance to and exit from the tidal delta, separated by year, Nisqually River Basin, Washington, 2004-08

\section{Conversion Factors}

SI to Inch/Pound

\begin{tabular}{lll}
\hline \multicolumn{1}{c}{ Multiply } & \multicolumn{1}{c}{ By } & \multicolumn{1}{c}{ To obtain } \\
\hline millimeter $(\mathrm{mm})$ & 0.03937 & inch $(\mathrm{in})$. \\
\hline millimeter per day $(\mathrm{mm} / \mathrm{d})$ & 0.03937 & foot per day $(\mathrm{ft} / \mathrm{d})$ \\
\hline
\end{tabular}

\section{Abbreviations and Acronyms}

$\begin{array}{ll}\text { ANOVA } & \text { Analysis of variance } \\ \text { DF } & \text { Delta-flats } \\ \text { DFCK } & \text { Delta-flats check } \\ \text { EEM } & \text { Estuarine Emergent Marsh } \\ \text { EFT } & \text { Emergent Forested Transition } \\ \text { ESA } & \text { Endangered Species Act } \\ \text { FRT } & \text { Forested Riverine Tidal } \\ \text { FW } & \text { Freshwater } \\ \text { MIW } & \text { Mean Increment Width } \\ \text { NS } & \text { Nearshore } \\ \text { PE } & \text { Pocket estuary } \\ \text { TDCK } & \text { Tidal delta check } \\ \text { USGS } & \text { United States Geological Survey } \\ \text { WFRC } & \text { Western Fisheries Research Center }\end{array}$




\title{
Otolith Analysis of Pre-Restoration Habitat Use by Chinook Salmon in the Delta-Flats and Nearshore Regions of the Nisqually River Estuary
}

\author{
By Angie Lind-Null and Kim Larsen
}

\begin{abstract}
The Nisqually Fall Chinook population is one of 27 salmon stocks in the Puget Sound (Washington) evolutionarily significant unit listed as threatened under the federal Endangered Species Act (ESA). Extensive restoration of the Nisqually River delta ecosystem is currently taking place to assist in recovery of the stock as juvenile Fall Chinook salmon are dependent on the estuary. A prerestoration baseline that includes the characterization of life history strategies, estuary residence times, growth rates, and habitat use is needed to evaluate the potential response of hatchery and natural origin Chinook salmon to restoration efforts and to determine restoration success. Otolith analysis was selected as a tool to examine Chinook salmon life history, growth, and residence in the Nisqually River estuary. Previously funded work on samples collected in 2004 (marked and unmarked) and 2005 (unmarked only) partially established a juvenile baseline on growth rates and length of residence associated with various habitats (freshwater, forested riverine tidal, emergent forested transition, estuarine emergent marsh, delta-flats and nearshore). However, residence times and growth rates for the delta-flats (DF) and nearshore (NS) habitats have been minimally documented due to small sample sizes. The purpose of the current study is to incorporate otolith microstructural analysis using otoliths from fish collected within the DF and NS habitats during sampling years 2004-08 to increase sample size and further evaluate between-year variation in otolith microstructure. Our results from this analysis indicated the delta-flats check (DFCK) on unmarked and marked Chinook samples in 2005-08 varied slightly in appearance from that seen on samples previously analyzed only from 2004. A fry migrant life history was observed on otoliths of unmarked Chinook collected in 2005, 2007, and 2008. Generally, freshwater mean increment width of unmarked fish, on average, was smaller compared to marked Chinook followed by tidal delta and DF/NS portions respectively. The average complete tidal delta and DF/NS growth rates for unmarked Chinook were consistently lower than for marked Chinook during all years; however, sample sizes were small during some years. The complete tidal delta and DF/NS growth rates were highest during 2008 compared to all other sampling years for both unmarked and marked Chinook. Unmarked Chinook, on average, spent longer in the tidal delta compared to marked Chinook. Our results from this report suggest that otolith microstructural analysis can be a valuable tool in establishing baseline information on the utilization of Nisqually River estuary habitats by juvenile Chinook salmon prior to the newly funded restoration efforts.
\end{abstract}




\section{Introduction}

The Nisqually Fall Chinook population is one of 27 salmon stocks in the Puget Sound (Washington) evolutionarily significant unit listed as threatened under the federal Endangered Species Act (ESA) (Nisqually Chinook Recovery Team, 2001). Extensive restoration of the Nisqually River delta is currently taking place to assist in recovery of the stock as juvenile Fall Chinook salmon are dependent on the estuary (Healey, 1980; Simenstad and others, 1982; Bottom and others, 2005). Restoration efforts include a return to tidal inundation in the delta providing additional delta habitat for juvenile salmonids. A pre-restoration baseline that includes the characterization of life history strategies, estuary residence time, growth rates, and habitat use is needed to evaluate the potential response of wild and hatchery Chinook salmon to restoration.

The analysis of otoliths, which are calcium carbonate structures in the inner ear, was selected as a tool to examine the life history, growth, and residence of Chinook salmon in the Nisqually River estuary. Otolith microstructure analysis generally is considered superior to traditional mark-recapture methods (Brothers, 1990). Mark-recapture methods can be extremely expensive (Volk and others, 1999), inadequate in estuary habitats, substantially underestimate habitat use, and do not directly reveal the relative contribution of juvenile life histories to adult recruitment. Such methods also do not account for differential survival of the fish during seaward migration. Analysis of otolith microstructure for these purposes is proving successful for the Nisqually wild and hatchery Chinook stocks as well as in a similar study that the U.S. Geological Survey (USGS) and its partner agencies are conducting in the Skagit River estuary in northern Puget Sound. This work is based on research by Neilson and others (1985).

Otoliths grow in proportion to the overall growth of the fish, therefore the daily growth increments of otoliths can be measured and counted to back-calculate fish size and estimate timing of various habitat transitions. Otolith microstructure can be analyzed to determine the number of days that a juvenile fish resided in an estuary (increment counts), size at entrance to the estuary, size at egress, and rate of growth within the estuary (Neilson and others, 1985). Juvenile Chinook salmon can exhibit a variety of life history strategies - some enter the sea (or Puget Sound) as fry (fry migrants), some rear in the estuary before they enter the sea (delta users), and some rear in the river and then move rapidly through the estuary to enter the sea as smolts (parr migrants) (Healey, 1991; Beamer and Larsen, 2004).

The long-term goals of this study are to use otoliths to compare differences in habitat use between wild and hatchery Chinook to further protect ESA listed stocks, determine if estuary restoration causes change to the population structure (i.e., frequency of the different life history strategies), compare pre- and post-restoration residence times and growth rates, and suggest whether estuary restoration yields substantial benefits for Chinook salmon (Miller and Simenstad, 1997).

Previously funded work on samples collected in 2004 (marked and unmarked) and 2005 (unmarked only) partially established a juvenile baseline on growth rates and length of residence associated with various habitats (freshwater, forested riverine tidal, emergent forested transition, estuarine emergent marsh, delta-flats and nearshore). However, residence times and growth rates for the delta-flats and nearshore habitats have been minimally documented due to small sample sizes. Those fish captured in the delta-flats and nearshore habitats provide a complete record of tidal delta growth rate and residence. The purpose of the current study is to incorporate microstructural analysis from the otoliths of fish collected within the delta-flats and nearshore habitats of the Nisqually River during sampling years 2004-08. The collection of juvenile Chinook from these particular habitats was chosen to increase sample size and further evaluate between-year variation in otolith microstructure. 


\section{Objectives}

1. Further develop a Nisqually-specific signature of otolith microstructural growth patterns and checks for the delta-flats and nearshore components, allowing us to fully distinguish growth and residence of juvenile salmon in the tidal delta habitat from growth in the delta-flats and nearshore habitats of the Nisqually River. Data for the otoliths of all fish sampled from the deltaflats and nearshore habitats for all sampling years (2004-08) will attempt to be pooled for analysis.

2. Further examine the unique aspects of estuarine utilization by one of the larger hatchery populations of juvenile Chinook salmon in Puget Sound by continuing to analyze the otoliths of remaining marked samples from the delta-flats and nearshore habitats collected in 2005-08 and to compare differences in estuarine utilization with wild Nisqually Chinook.

\section{Methods}

Unmarked and marked juvenile Chinook salmon were sampled by the Nisqually Indian Tribe and the U.S. Fish and Wildlife Service - Nisqually National Wildlife Refuge from March through October 2004, February through October 2005, 2006, and 2008, and from February through June 2007. No unmarked fish were collected in the delta-flats during 2006 and no sampling occurred in the deltaflats during 2007. Sampling sites included the lower Nisqually River, the tidally influenced region of the estuary near the river's mouth (hereafter referred to as tidal delta), and the shallow subtidal and intertidal areas (accessible by beach seine; hereafter referred to as delta-flats, nearshore, and pocket estuary) outside of the Nisqually delta complex. Most fish were collected by beach seining in the following distinct habitat zones (Cowardin and others, 1979; fig. 1):

1. Freshwater $(\mathrm{FW})$ - forested slow-water habitat on the mainstem Nisqually River without tidal influence.

2. Forested Riverine Tidal (FRT) - riparian forest, mud/silt substrate, and tidal influence (uppermost portion of the tidal delta).

3. Emergent Forested Transition (EFT) - scrub/shrub and marsh vegetation, mud/silt substrate, and tidal influence (tidal delta).

4. Estuarine Emergent Marsh (EEM) - low and high salt marsh vegetation, mud substrate, and full tidal influence (lowermost portion of the tidal delta).

5. Delta-Flats (DF) - sparse to no vegetation, mud or gravel/cobble substrate, and large tidal fluctuations.

6. Nearshore (NS) - saltwater, shallow subtidal and intertidal areas, vegetation and substrate variable.

7. Pocket Estuary (PE) - sand-spit enclosed estuary with salt marsh vegetation, sand and mud substrate, and forested bluffs.

A few sites within the EEM habitat were sampled with fyke nets. In 2005, fyke trapping ended in August. 


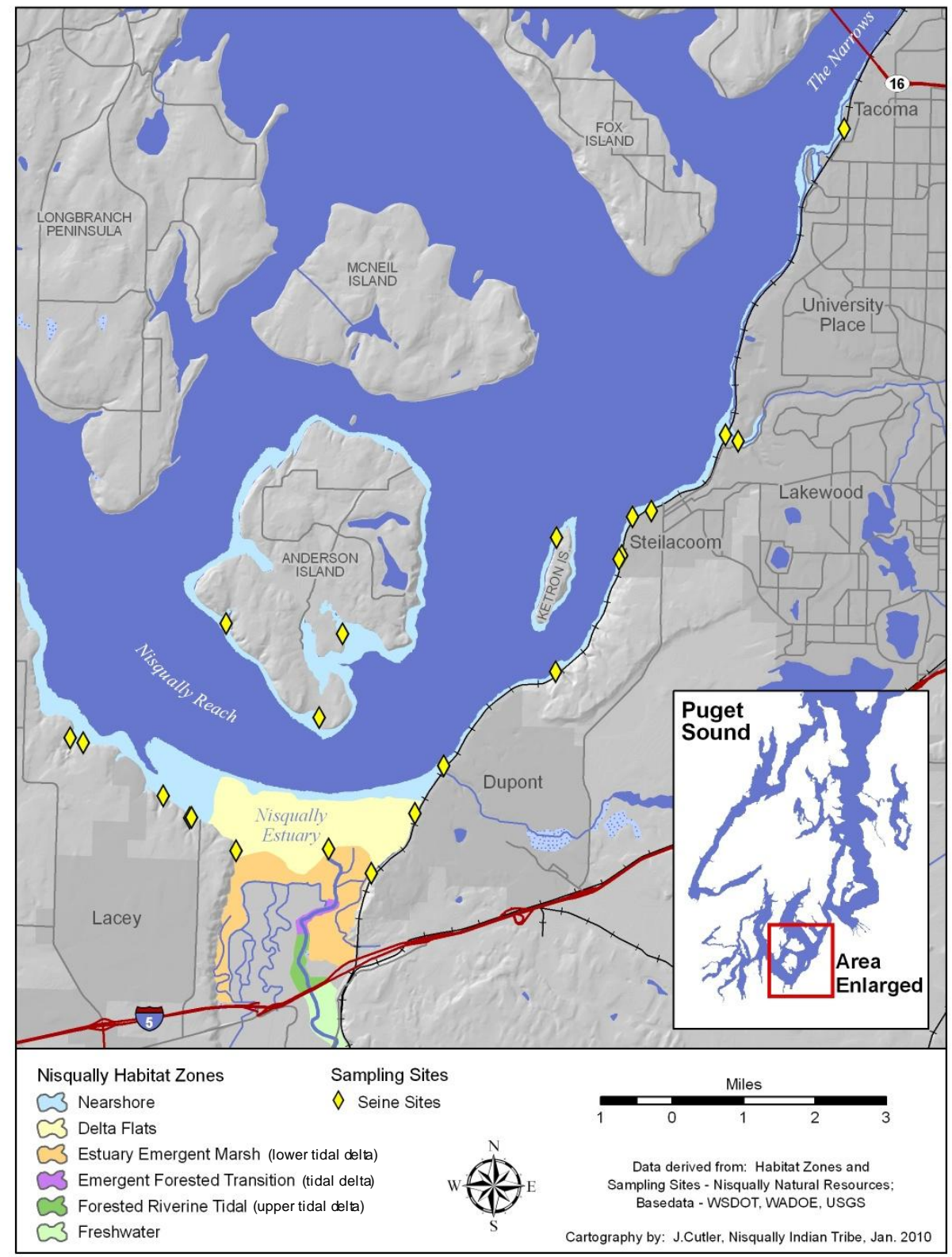

Figure 1. Distinct habitat zones of the lower Nisqually River with field sampling sites shown for the nearshore (NS) and delta-flats (DF) habitats (2004-08). 
Juvenile Chinook were collected and subsampled for otolith extraction. Each fish was euthanized and measured for length and weight. The fish were preserved in alcohol and sent to USGS, Western Fisheries Research Center (WFRC), where the sagittal otoliths of unmarked and marked fish were extracted. A total of 474 pairs of otoliths were extracted from unmarked and marked fish collected within the DF and NS habitats during 2004-08 (table 1). All otoliths (one from each pair) from fish collected within DF and NS habitats were processed according to the WFRC's standard protocols, excluding those with a coded wire tag from other than the Nisqually River $(n=28)$ and unmarked (2004$05)$ and marked (2004) samples previously processed from the DF $(n=114)$ and NS $(n=43)$ habitats. The total sample size was supplemented with 17 complementary right otoliths of equal length. Seven additional samples were not processed due to otolith misplacement or vaterite formation (vaterite is a crystalline morph of calcium carbonate), for a total of 439 samples available for analysis.

Table 1. Number of unmarked and marked juvenile Chinook salmon collected for otolith analysis in the delta-flats (DF) and nearshore (NS) habitats, Nisqually River Basin, Washington, 2004-08.

[Total number includes non-Nisqually coded wire tagged fish and unmarked (2004-05) and marked (2004) samples previously processed from delta-flats (DF) and nearshore (NS) habitats. Additional fish were collected in other habitats but are not listed here]

\begin{tabular}{|c|c|c|c|c|c|c|c|c|c|c|c|c|}
\hline Origin & Year & Habitat Type & Feb. & Mar. & Apr. & May & June & July & Aug. & Sept. & Oct. & TOTAL \\
\hline \multirow[t]{10}{*}{ Unmarked } & \multirow[t]{2}{*}{2004} & Delta-flats (DF) & 0 & 0 & 13 & 3 & 17 & 3 & 0 & 0 & 0 & 36 \\
\hline & & Nearshore (NS) & 0 & 0 & 0 & 0 & 2 & 0 & 0 & 0 & 0 & 2 \\
\hline & \multirow[t]{2}{*}{2005} & Delta-flats (DF) & 1 & 1 & 9 & 2 & 10 & 1 & 0 & 0 & 0 & 24 \\
\hline & & Nearshore (NS) & 0 & 0 & 0 & 2 & 5 & 1 & 0 & 0 & 0 & 8 \\
\hline & \multirow[t]{2}{*}{2006} & Delta-flats (DF) & 0 & 0 & 0 & 0 & 0 & 0 & 0 & 0 & 0 & 0 \\
\hline & & Nearshore (NS) & 0 & 0 & 1 & 13 & 1 & 2 & 2 & 0 & 0 & 19 \\
\hline & \multirow[t]{2}{*}{2007} & Delta-flats (DF) & 0 & 0 & 0 & 0 & 0 & 0 & 0 & 0 & 0 & 0 \\
\hline & & Nearshore (NS) & 0 & 8 & 13 & 6 & 8 & 0 & 0 & 0 & 0 & 35 \\
\hline & \multirow[t]{2}{*}{2008} & Delta-flats (DF) & 0 & 5 & 6 & 9 & 13 & 0 & 0 & 0 & 0 & 33 \\
\hline & & Nearshore (NS) & 0 & 1 & 3 & 4 & 5 & 0 & 1 & 0 & 0 & 14 \\
\hline \multirow[t]{10}{*}{ Marked } & \multirow[t]{2}{*}{2004} & Delta-flats (DF) & 0 & 0 & 4 & 15 & 25 & 9 & 0 & 1 & 0 & 54 \\
\hline & & Nearshore (NS) & 0 & 0 & 0 & 7 & 7 & 0 & 0 & 0 & 0 & 14 \\
\hline & \multirow[t]{2}{*}{2005} & Delta-flats (DF) & 0 & 0 & 5 & 17 & 12 & 4 & 0 & 0 & 0 & 38 \\
\hline & & Nearshore (NS) & 0 & 0 & 0 & 15 & 9 & 3 & 0 & 0 & 0 & 27 \\
\hline & \multirow[t]{2}{*}{2006} & Delta-flats (DF) & 0 & 0 & 0 & 9 & 0 & 0 & 0 & 0 & 0 & 9 \\
\hline & & Nearshore (NS) & 0 & 0 & 0 & 24 & 7 & 2 & 2 & 0 & 0 & 35 \\
\hline & \multirow[t]{2}{*}{2007} & Delta-flats (DF) & 0 & 0 & 0 & 0 & 0 & 0 & 0 & 0 & 0 & 0 \\
\hline & & Nearshore (NS) & 0 & 12 & 5 & 31 & 13 & 0 & 0 & 0 & 0 & 61 \\
\hline & \multirow[t]{3}{*}{2008} & Delta-flats (DF) & 0 & 0 & 2 & 11 & 14 & 0 & 0 & 0 & 0 & 27 \\
\hline & & Nearshore (NS) & 0 & 1 & 0 & 24 & 13 & 0 & 0 & 0 & 0 & 38 \\
\hline & & TOTAL & 1 & 28 & 61 & 192 & 161 & 25 & 5 & 1 & 0 & 474 \\
\hline
\end{tabular}


In addition, marked juvenile Chinook were collected in 2004-08 directly from the Clear Creek and Kalama hatcheries $(n=361)$ less than two weeks prior to hatchery release. An average of 15 fish per hatchery group was sacrificed and the otoliths of at least eight fish per hatchery group were processed and analyzed to determine unique microstructural patterns specific to each hatchery. This number of samples was selected because of the consistent incremental otolith pattern exhibited by hatchery fish under constant rearing conditions and to minimize the number of sacrificed fish. Juvenile Chinook salmon collected from the hatcheries in 2004-05 were previously processed and analyzed ( $\mathrm{n}=62)$ and hatchery samples collected in 2007-08 were processed and analyzed $(n=64)$ under this proposal. The hatchery fish collected in 2006 were misplaced and therefore unavailable for otolith analysis.

The otolith microstructure of all unmarked samples was analyzed for potential hatchery origin by examination of unique hatchery patterns as mentioned above. The samples were then categorized as Clear Creek hatchery, Kalama hatchery or wild origin. We focused specifically on separating samples from hatcheries that release fish directly into the Nisqually River (the Clear Creek and Kalama hatcheries). However, if the fish's otolith microstructure was obviously from another South Sound hatchery, based on archived hatchery patterns, the sample was separated from the dataset and not included in the analysis. Unmarked samples identified as hatchery origin or marked samples with an otolith microstructure pattern other than Clear Creek or Kalama hatchery were not analyzed. Samples not distinguishable as hatchery or wild origin were categorized as "unknown origin" and were not analyzed further.

A total of 55 unmarked fish were identified as hatchery origin, 302 as wild, and three as unknown (table 2). Nine marked samples were excluded from the analysis because their microstructure revealed a non-Nisqually hatchery pattern. Seventy-three additional samples were not suitable for analysis because of uneven microstructural growth along the radial axis or processing error. In total, 302 samples were analyzed out of the 439 available (table 3 ).

Table 2. Number of unmarked hatchery samples separated from the dataset.

\begin{tabular}{|c|c|c|c|c|c|c|c|c|c|c|c|}
\hline Year & Habitat Type & Feb. & Mar. & Apr. & May & June & July & Aug. & Sept. & Oct. & TOTAL \\
\hline \multirow[t]{2}{*}{2004} & Delta-flats (DF) & 0 & 0 & 5 & 1 & 8 & 2 & 0 & 0 & 0 & 16 \\
\hline & Nearshore (NS) & 0 & 0 & 0 & 0 & 0 & 0 & 0 & 0 & 0 & 0 \\
\hline \multirow[t]{2}{*}{2005} & Delta-flats (DF) & 0 & 0 & 0 & 1 & 0 & 0 & 0 & 0 & 0 & 1 \\
\hline & Nearshore (NS) & 0 & 0 & 2 & 4 & 0 & 0 & 0 & 0 & 0 & 6 \\
\hline \multirow[t]{2}{*}{2006} & Delta-flats (DF) & 0 & 0 & 0 & 0 & 0 & 0 & 0 & 0 & 0 & 0 \\
\hline & Nearshore (NS) & 0 & 1 & 7 & 0 & 0 & 2 & 0 & 0 & 0 & 10 \\
\hline \multirow[t]{2}{*}{2007} & Delta-flats (DF) & 0 & 0 & 0 & 0 & 0 & 0 & 0 & 0 & 0 & 0 \\
\hline & Nearshore (NS) & 0 & 7 & 10 & 2 & 0 & 0 & 0 & 0 & 0 & 19 \\
\hline \multirow[t]{3}{*}{2008} & Delta-flats (DF) & 0 & 0 & 0 & 0 & 0 & 0 & 0 & 0 & 0 & 0 \\
\hline & Nearshore (NS) & 0 & 0 & 0 & 1 & 2 & 0 & 0 & 0 & 0 & 3 \\
\hline & TOTAL & 0 & 8 & 24 & 9 & 10 & 4 & 0 & 0 & 0 & 55 \\
\hline
\end{tabular}


Table 3. Number of otoliths (one per fish) analyzed/processed.

[The number analyzed does not include unmarked hatchery fish separated from the dataset after processing]

\begin{tabular}{|c|c|c|c|c|c|c|c|c|c|c|c|c|}
\hline Origin & Year & Habitat Type & Feb. & Mar. & Apr. & May & June & July & Aug. & Sept. & Oct. & TOTAL \\
\hline \multirow[t]{10}{*}{ Unmarked } & \multirow[t]{2}{*}{2004} & Delta-flats (DF) & $0 / 0$ & $0 / 0$ & $5 / 13$ & $1 / 3$ & $6 / 17$ & $0 / 3$ & $0 / 0$ & $0 / 0$ & $0 / 0$ & $12 / 36$ \\
\hline & & Nearshore (NS) & $0 / 0$ & $0 / 0$ & $0 / 0$ & $0 / 0$ & $1 / 2$ & $0 / 0$ & $0 / 0$ & $0 / 0$ & $0 / 0$ & $1 / 2$ \\
\hline & \multirow[t]{2}{*}{2005} & Delta-flats (DF) & $1 / 1$ & $1 / 1$ & $9 / 9$ & $1 / 2$ & $10 / 10$ & $1 / 1$ & $0 / 0$ & $0 / 0$ & $0 / 0$ & $23 / 24$ \\
\hline & & Nearshore (NS) & $0 / 0$ & $0 / 0$ & $0 / 0$ & $0 / 2$ & $1 / 5$ & $1 / 1$ & $0 / 0$ & $0 / 0$ & $0 / 0$ & $2 / 8$ \\
\hline & \multirow[t]{2}{*}{2006} & Delta-flats (DF) & $0 / 0$ & $0 / 0$ & $0 / 0$ & $0 / 0$ & $0 / 0$ & $0 / 0$ & $0 / 0$ & $0 / 0$ & $0 / 0$ & $0 / 0$ \\
\hline & & Nearshore (NS) & $0 / 0$ & $0 / 0$ & $0 / 1$ & $4 / 13$ & $1 / 1$ & $0 / 2$ & $0 / 2$ & $0 / 0$ & $0 / 0$ & $5 / 19$ \\
\hline & \multirow[t]{2}{*}{2007} & Delta-flats (DF) & $0 / 0$ & $0 / 0$ & $0 / 0$ & $0 / 0$ & $0 / 0$ & $0 / 0$ & $0 / 0$ & $0 / 0$ & $0 / 0$ & $0 / 0$ \\
\hline & & Nearshore (NS) & $0 / 0$ & $1 / 8$ & $2 / 13$ & $3 / 6$ & $3 / 8$ & $0 / 0$ & $0 / 0$ & $0 / 0$ & $0 / 0$ & $9 / 35$ \\
\hline & \multirow[t]{2}{*}{2008} & Delta-flats (DF) & $0 / 0$ & $4 / 5$ & $6 / 6$ & $9 / 9$ & $13 / 13$ & $0 / 0$ & $0 / 0$ & $0 / 0$ & $0 / 0$ & $32 / 33$ \\
\hline & & Nearshore (NS) & $0 / 0$ & $1 / 1$ & $2 / 3$ & $2 / 4$ & $3 / 5$ & $0 / 0$ & $0 / 1$ & $0 / 0$ & $0 / 0$ & $8 / 14$ \\
\hline \multirow[t]{10}{*}{ Marked } & \multirow[t]{2}{*}{2004} & Delta-flats (DF) & $0 / 0$ & $0 / 0$ & $0 / 2$ & $12 / 13$ & $19 / 22$ & $5 / 6$ & $0 / 0$ & $0 / 1$ & $0 / 0$ & $36 / 44$ \\
\hline & & Nearshore (NS) & $0 / 0$ & $0 / 0$ & $0 / 0$ & $7 / 7$ & $5 / 5$ & $0 / 0$ & $0 / 0$ & $0 / 0$ & $0 / 0$ & $12 / 12$ \\
\hline & \multirow[t]{2}{*}{2005} & Delta-flats (DF) & $0 / 0$ & $0 / 0$ & $5 / 5$ & $15 / 16$ & $5 / 6$ & $0 / 1$ & $0 / 0$ & $0 / 0$ & $0 / 0$ & $25 / 28$ \\
\hline & & Nearshore (NS) & $0 / 0$ & $0 / 0$ & $0 / 0$ & $15 / 15$ & $4 / 6$ & $3 / 3$ & $0 / 0$ & $0 / 0$ & $0 / 0$ & $22 / 24$ \\
\hline & \multirow[t]{2}{*}{2006} & Delta-flats (DF) & $0 / 0$ & $0 / 0$ & $0 / 0$ & $6 / 7$ & $0 / 0$ & $0 / 0$ & $0 / 0$ & $0 / 0$ & $0 / 0$ & $6 / 7$ \\
\hline & & Nearshore (NS) & $0 / 0$ & $0 / 0$ & $0 / 0$ & $20 / 24$ & $5 / 7$ & $0 / 2$ & $1 / 1$ & $0 / 0$ & $0 / 0$ & $26 / 34$ \\
\hline & \multirow[t]{2}{*}{2007} & Delta-flats (DF) & $0 / 0$ & $0 / 0$ & $0 / 0$ & $0 / 0$ & $0 / 0$ & $0 / 0$ & $0 / 0$ & $0 / 0$ & $0 / 0$ & $0 / 0$ \\
\hline & & Nearshore (NS) & $0 / 0$ & $0 / 12$ & $2 / 5$ & $21 / 27$ & $9 / 10$ & $0 / 0$ & $0 / 0$ & $0 / 0$ & $0 / 0$ & $32 / 54$ \\
\hline & \multirow[t]{2}{*}{2008} & Delta-flats (DF) & $0 / 0$ & $0 / 0$ & $1 / 2$ & $10 / 11$ & $10 / 14$ & $0 / 0$ & $0 / 0$ & $0 / 0$ & $0 / 0$ & $21 / 27$ \\
\hline & & Nearshore (NS) & $0 / 0$ & $1 / 1$ & $0 / 0$ & $17 / 24$ & $12 / 13$ & $0 / 0$ & $0 / 0$ & $0 / 0$ & $0 / 0$ & $30 / 38$ \\
\hline & & TOTAL & $1 / 1$ & $8 / 28$ & $32 / 59$ & $143 / 183$ & $107 / 144$ & $10 / 19$ & $1 / 4$ & $0 / 1$ & $0 / 0$ & $302 / 439$ \\
\hline
\end{tabular}


As referenced in our previous reports (Lind-Null and others, 2008a, 2008b; Lind-Null and Larsen, 2009), fish collected from FW showed a consistently recognizable pattern that was used as a reference for all fish otoliths collected downstream of FW habitat. This reference pattern had no checks beyond the recognizable checks associated with emergence (unmarked samples only) and first feed (unmarked and marked samples). A check is a consistently prominent mark or pattern on the otolith that interrupts the normal sequence of otolith deposition (Campana, 1983). Each increment was interpreted as one day's growth for the fish (Stevenson and Campana, 1992). Otoliths from fish collected in DF and NS habitats were visually analyzed for additional patterns, checks, or increased growth beyond the identifiers observed on the FW residence portion of the otoliths.

Daily growth increments and checks in the otolith microstructure were measured with ImagePro, an imaging analysis software program. A standardized radial axis was selected for measurements at $85 \pm 5$ degrees dorsal to the longitudinal axis passing through an identifiable and preferred nucleus. Distances and individual increment widths between checks were measured along the radial axis, from the otolith's core to its edge. Increases in growth assumed to represent change in habitat were also recorded for each fish along the radial axis.

Residence times were translated from increment counts between habitat zones. Growth rates in the DF and NS habitats were calculated in millimeters per day $(\mathrm{mm} / \mathrm{d})$ from lengths based on the FraserLee method (DeVries and Frie, 1996), using the following equation:

$$
L_{i}=\frac{L_{c}-a}{S_{c}} S_{i}+a
$$

where

$L_{i}$ is the back-calculated length of the fish at the beginning of a habitat transition,

$L_{c}$ is the length of the fish at capture,

$S_{c}$ is the radius of the otolith at capture,

$S_{i}$ is the radius of the otolith at the beginning of a habitat transition, and

$a$ is the intercept from the regression separated by year of capture fork length verses otolith radius (fig. 2).

An overall linear regression of capture fork length verses otolith radius for all sampling years combined was completed (fig. 2, panel F). Average mean increment widths (MIW) in microns $(\mu \mathrm{m})$ and complete tidal delta and DF/NS growth rates for the DF and NS habitat zones were determined. Growth rates were calculated with the intercept of the regression for a given sampling year due to inter-annual differences. Complete tidal delta residence time and fork lengths upon entry to and exit from the tidal delta also were calculated (Sokal and Rohlf, 1981; Campana and Jones, 1992). 

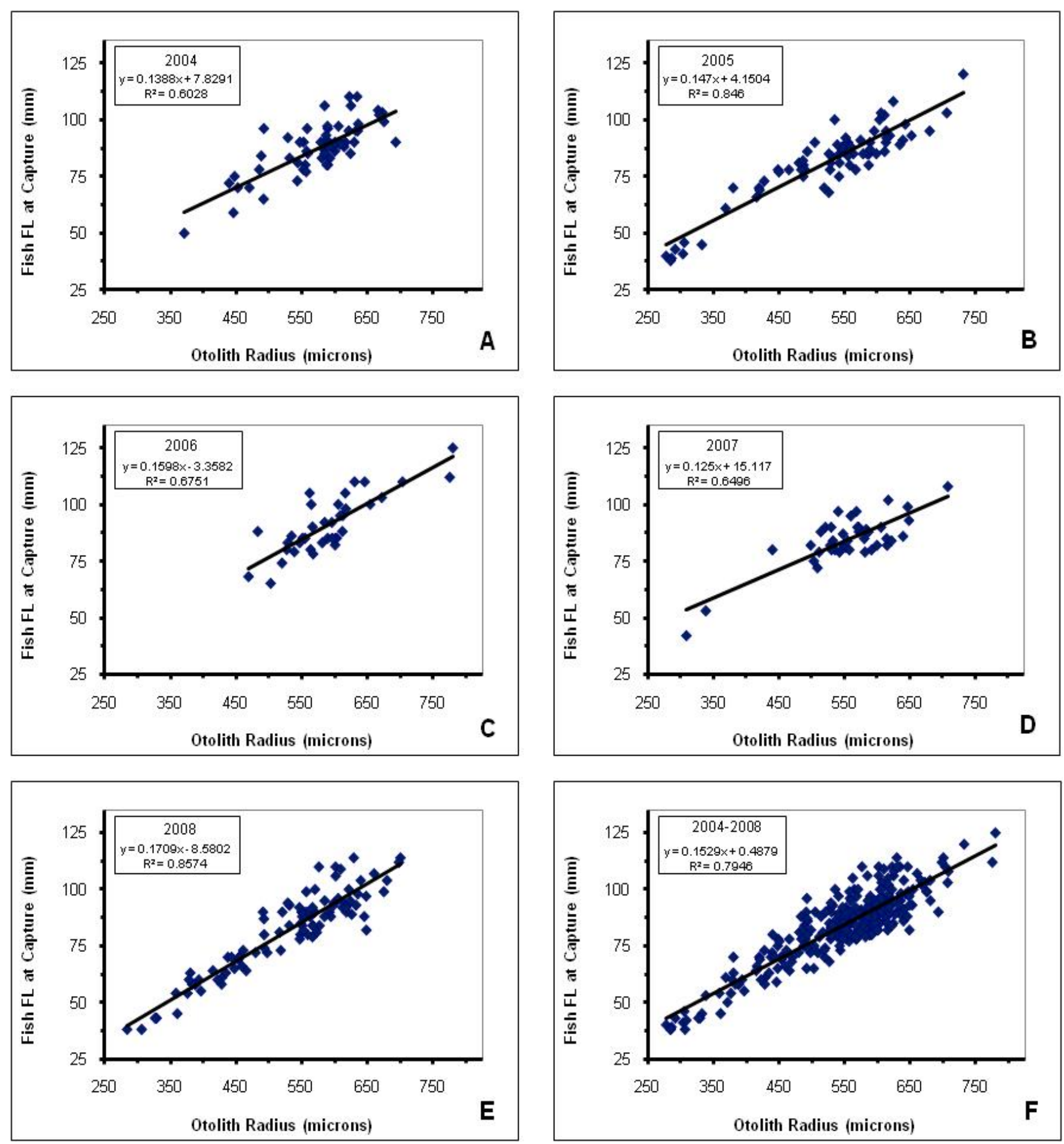

Figure 2. Relationship between fish fork length (in millimeters) and otolith radial distance (in microns). The data represents samples collected in the delta-flats (DF) and nearshore (NS) habitats of the Nisqually River Basin, Washington, 2004-08. Each panel represents an individual sampling year except for panel $F: A=2004, B=2005$, $C=2006, D=2007, E=2008$, and $F=a l l$ years combined $(2004-08)$. 


\section{Results}

The increments on all otoliths became more legible and consistent across the radial axis beyond the emergence (unmarked samples only) or first feed (unmarked and marked samples) checks (fig. 3). An interruption in the microstructure, designated as a tidal delta check (TDCK), was observed on samples indicating a transition to tidal delta habitat (table 4). Increments were consistently thin, with narrow spacing across the radial axis until the TDCK was observed. At this point, the increments became consistently thicker with wider spacing indicating an increase in growth with transition from FW habitat to tidal delta habitat. Otoliths from juvenile Chinook salmon previously collected within FW and FRT habitats were analyzed and did not display a TDCK or increase in growth. The TDCK looked similar between years and fish origin, however marked fish had fewer TDCK increments than unmarked.

In addition to the TDCK, another check was visible on some otoliths collected in the DF and NS habitats. As referenced in previous reports (Lind-Null and others, 2008a, 2008b; Lind-Null and Larsen, 2009), we called this a delta-flats check (DFCK) due to classification of sites. The DFCK indicated the fish's transition from tidal delta habitat to the DF and NS habitats. The DFCK looked similar between years and fish origin except for 2004, when the check included one additional increment.

We tested for differences between unmarked and marked Chinook in MIW, complete tidal delta and DF/NS growth rates, complete tidal delta residence times, and fork lengths at entrance and exit to the tidal delta. Unmarked and marked data were not combined due to significant differences (one-way ANOVA) in complete tidal delta growth rate $(\mathrm{P} \leq 0.0043)$, complete tidal delta residence time $(\mathrm{P} \leq 0.0001)$, fork length at entrance to tidal delta $(\mathrm{P} \leq 0.0001)$, fork length at exit from the tidal delta $(\mathrm{P} \leq 0.0017)$, DF/NS MIW $(\mathrm{P} \leq 0.0077)$ and $\mathrm{DF} / \mathrm{NS}$ growth rate $(\mathrm{P} \leq 0.0294)$. On average, the MIW on the otoliths for all habitats (FW, tidal delta, DF and NS) of unmarked Chinook was lower respectively compared to that of the marked Chinook regardless of the year, except in 2008 (fig. 4). In 2008, unmarked Chinook $(n=2)$ had a slightly higher DF/NS MIW compared to marked Chinook $(n=1)$, though sample sizes were small. The average complete tidal delta growth rate for unmarked Chinook was lower than that for marked Chinook for all years (fig. 5). On average, unmarked Chinook (mean $=0.47 \mathrm{~mm} /$ day, $\mathrm{n}=21$ ) had a lower complete tidal delta growth rate compared to that for marked Chinook (mean $=0.55 \mathrm{~mm} /$ day, $\mathrm{n}=20$ ). The average $\mathrm{DF} / \mathrm{NS}$ growth rate for unmarked Chinook was consistently lower compared to that of the marked Chinook for all years, however sample sizes are small (fig. 6).

The increments on all otoliths became more legible and consistent across the radial axis beyond the emergence (unmarked samples only) or first feed (unmarked and marked samples) checks (fig. 3). An interruption in the microstructure, designated as a tidal delta check (TDCK), was observed on samples indicating a transition to tidal delta habitat (table 4). Increments were consistently thin, with narrow spacing across the radial axis until the TDCK was observed. At this point, the increments became consistently thicker with wider spacing indicating an increase in growth with transition from FW habitat to tidal delta habitat. Otoliths from juvenile Chinook salmon previously collected within FW and FRT habitats were analyzed and did not display a TDCK or increase in growth. The TDCK looked similar between years and fish origin, however marked fish had fewer TDCK increments than unmarked. 
Table 4. Number of otoliths (one per fish) with a tidal delta check (TDCK) or delta-flats check (DFCK).

[Dashes represent those fish not displaying a TDCK or DFCK]

\begin{tabular}{|c|c|c|c|c|c|c|c|c|c|c|c|c|c|c|c|c|}
\hline \multirow[b]{2}{*}{ Origin } & \multirow[b]{2}{*}{ Year } & \multirow[b]{2}{*}{ Habitat Type } & \multicolumn{2}{|c|}{ Feb. } & \multicolumn{2}{|c|}{ Mar. } & \multicolumn{2}{|c|}{ Apr. } & \multicolumn{2}{|c|}{ May } & \multicolumn{2}{|c|}{ June } & \multicolumn{2}{|c|}{ July } & \multicolumn{2}{|c|}{ Aug. } \\
\hline & & & TDCK & DFCK & TDCK & DFCK & TDCK & DFCK & TDCK & DFCK & TDCK & DFCK & TDCK & DFCK & TDCK & DFCK \\
\hline \multirow{10}{*}{ Unmarked } & \multirow{2}{*}{2004} & Delta-flats (DF) & - & - & - & - & 5 & 4 & 1 & - & 6 & 5 & - & - & - & - \\
\hline & & Nearshore (NS) & - & - & - & - & - & - & - & - & 1 & - & - & - & - & - \\
\hline & \multirow{2}{*}{2005} & Delta-flats (DF) & - & - & - & 1 & 1 & 5 & 1 & 1 & 9 & 6 & 1 & 1 & - & - \\
\hline & & Nearshore (NS) & - & - & - & - & - & - & - & - & 1 & - & 1 & 1 & - & - \\
\hline & \multirow[t]{2}{*}{2006} & Delta-flats (DF) & - & - & - & - & - & - & - & - & - & - & - & - & - & - \\
\hline & & Nearshore (NS) & - & - & - & - & - & - & 4 & - & 1 & - & - & - & - & - \\
\hline & \multirow[t]{2}{*}{2007} & Delta-flats (DF) & - & - & - & - & - & - & - & - & - & - & - & - & - & - \\
\hline & & Nearshore (NS) & - & - & - & 1 & - & - & 1 & 1 & 2 & - & - & - & - & - \\
\hline & \multirow{2}{*}{2008} & Delta-flats (DF) & - & - & - & - & 3 & - & 5 & 2 & 2 & - & - & - & - & - \\
\hline & & Nearshore (NS) & - & - & - & 1 & - & 1 & - & - & 2 & - & - & - & - & - \\
\hline \multirow[t]{10}{*}{ Marked } & \multirow[t]{2}{*}{2004} & Delta-flats (DF) & - & - & - & - & - & - & 1 & - & 14 & - & 4 & 3 & - & - \\
\hline & & Nearshore (NS) & - & - & - & - & - & - & 6 & - & 4 & - & - & - & - & - \\
\hline & \multirow[t]{2}{*}{2005} & Delta-flats (DF) & - & - & - & - & - & - & 7 & 5 & 5 & 3 & - & - & - & - \\
\hline & & Nearshore (NS) & - & - & - & - & - & - & 5 & - & 3 & 1 & 3 & 3 & - & - \\
\hline & \multirow{2}{*}{2006} & Delta-flats (DF) & - & - & - & - & - & - & 1 & - & - & - & - & - & - & - \\
\hline & & Nearshore (NS) & - & - & - & - & - & - & 5 & - & 1 & - & - & - & 1 & 1 \\
\hline & \multirow{2}{*}{2007} & Delta-flats (DF) & - & - & - & - & - & - & - & - & - & - & - & - & - & - \\
\hline & & Nearshore (NS) & - & - & - & - & - & - & 3 & - & 7 & 3 & - & - & - & - \\
\hline & \multirow[t]{2}{*}{2008} & Delta-flats (DF) & - & - & - & - & - & - & 1 & - & 2 & - & - & - & - & - \\
\hline & & Nearshore (NS) & - & - & - & - & - & - & 5 & 1 & 4 & - & - & - & - & - \\
\hline & & TOTAL & - & - & - & 3 & 9 & 10 & 46 & 10 & 64 & 18 & 9 & 8 & 1 & 1 \\
\hline
\end{tabular}




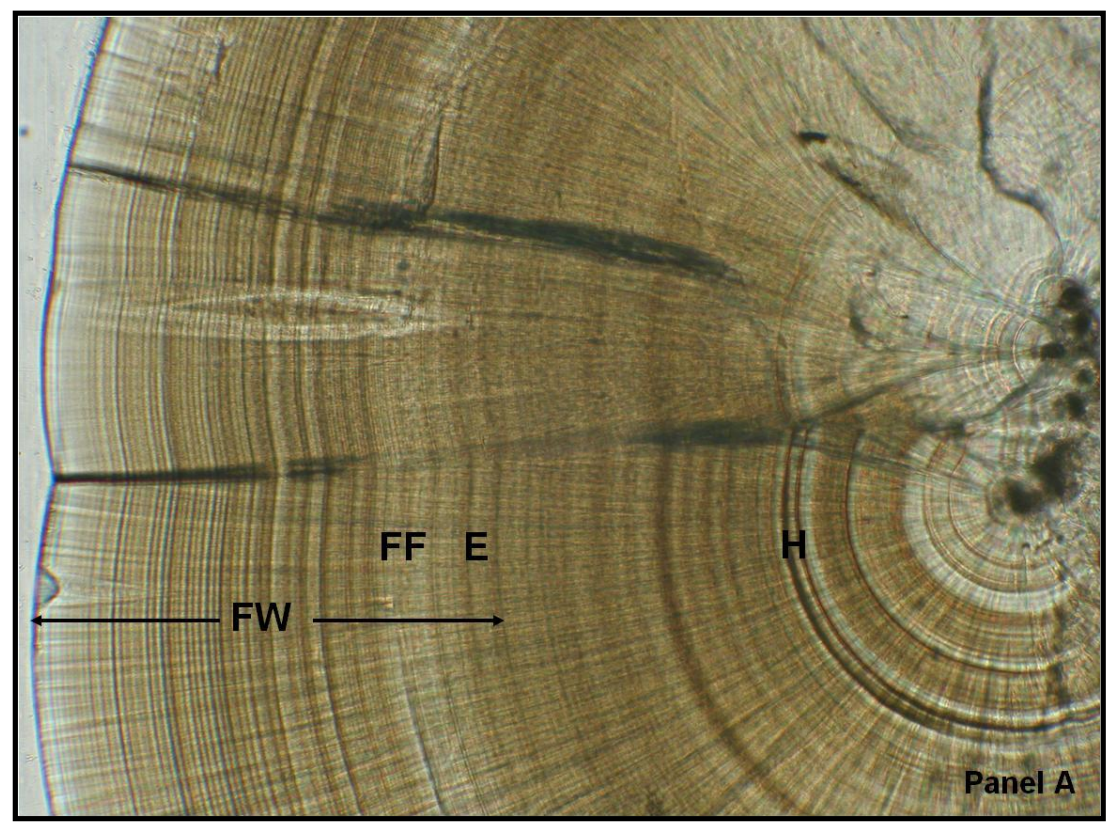

20x objective

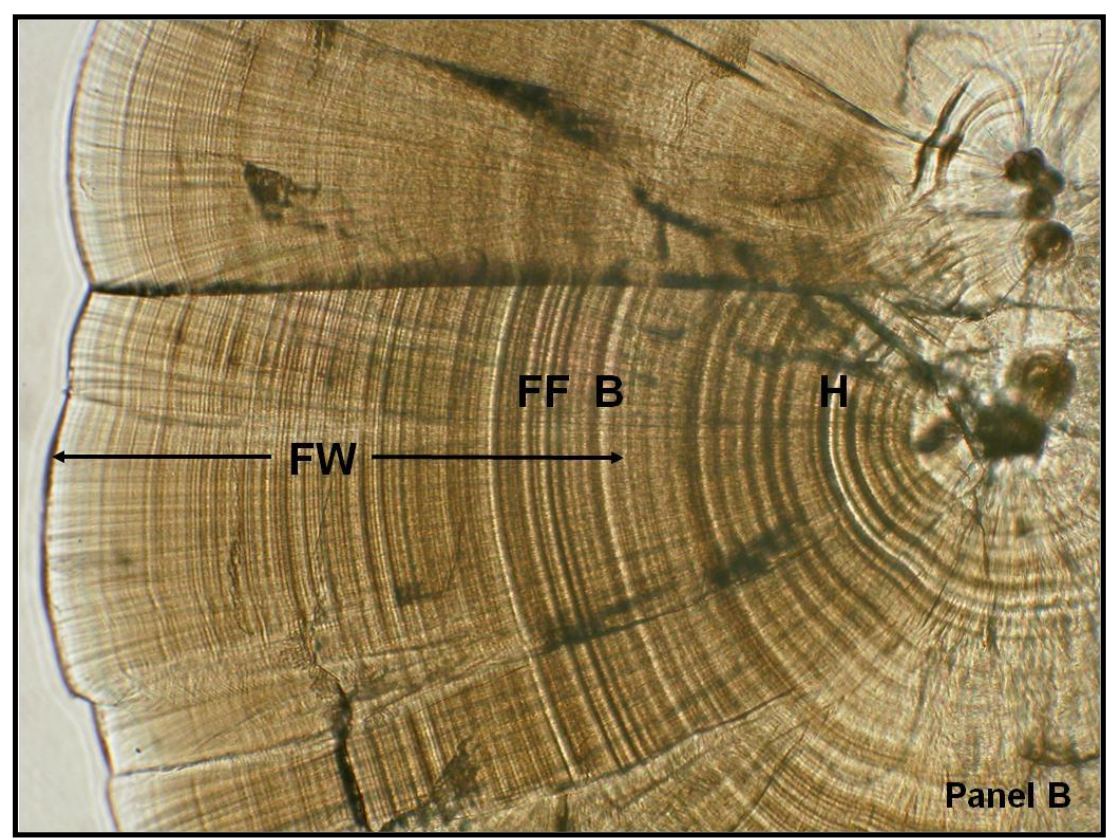

20x objective

Figure 3. Representative unmarked (panel A) and marked (panel B) otolith samples of freshwater (FW) growth in juvenile Chinook salmon collected from Nisqually River Basin, Washington, 2004-08. Abbreviations: $H=$ hatch, $E=$ emergence, $\mathrm{B}=$ button-up, $\mathrm{FF}=$ first feed, and FW $=\mathrm{FW}$ residence. 

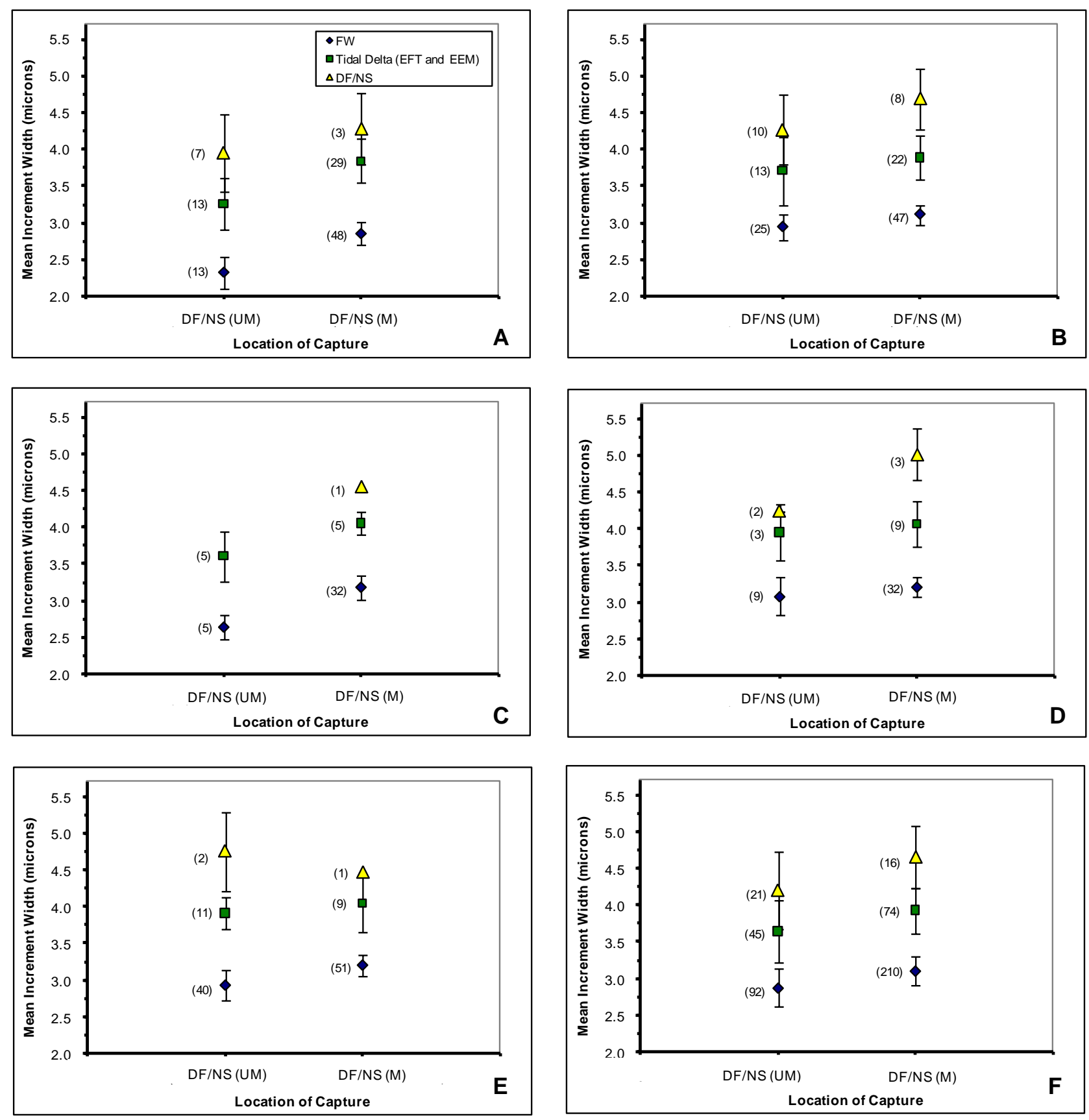

Figure 4. Mean increment width (MIW; microns) of the freshwater (FW), tidal delta, and delta-flats/nearshore (DF/NS) portions of the otolith for unmarked and marked juvenile Chinook salmon residing in the delta-flats (DF) and nearshore (NS) habitat zones, Nisqually River Basin, Washington, 2004-08. Nine unmarked samples collected in the DF $(n=2)$ and NS ( $n=7)$ habitats and four marked samples collected in the DF habitat were excluded from the DF/NS portion of the MIW analysis because residence time was only two days or less. In addition, two unmarked samples collected in the DF and eight marked samples collected in the DF $(n=1)$ and NS $(n=7)$ were excluded from the tidal delta portion of the MIW analysis because residence time was only two days or less. Sample size (n) is represented in parentheses. Error bars represent \pm 1 standard deviation. Each panel represents an individual

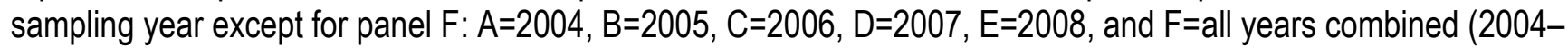
08). 


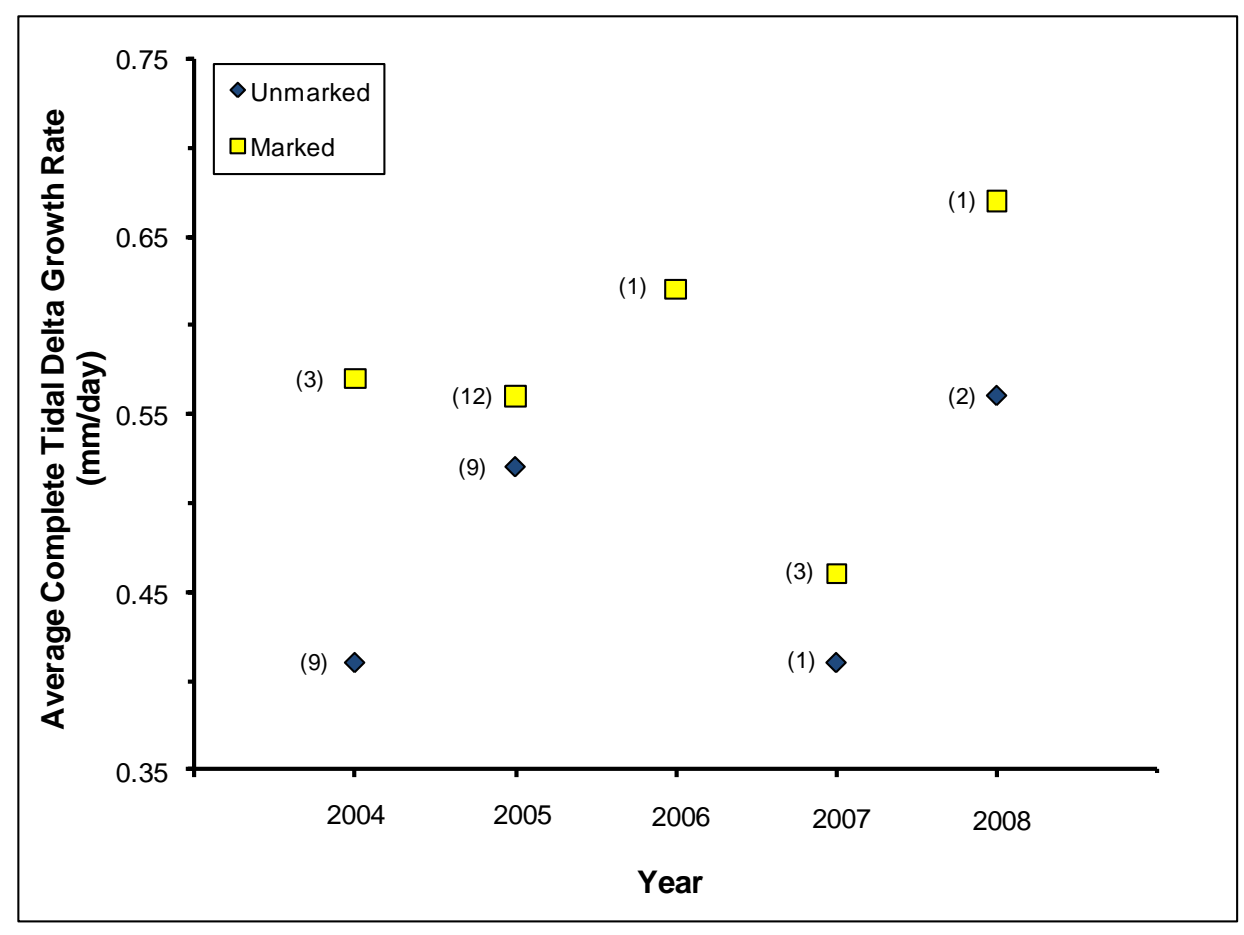

Figure 5. Average complete tidal delta growth rate $(\mathrm{mm} / \mathrm{day})$ by year for unmarked and marked juvenile Chinook salmon collected from the delta-flats (DF) and nearshore (NS) habitats, Nisqually River Basin, Washington, 200408. Sample size $(n)$ is represented in parentheses.

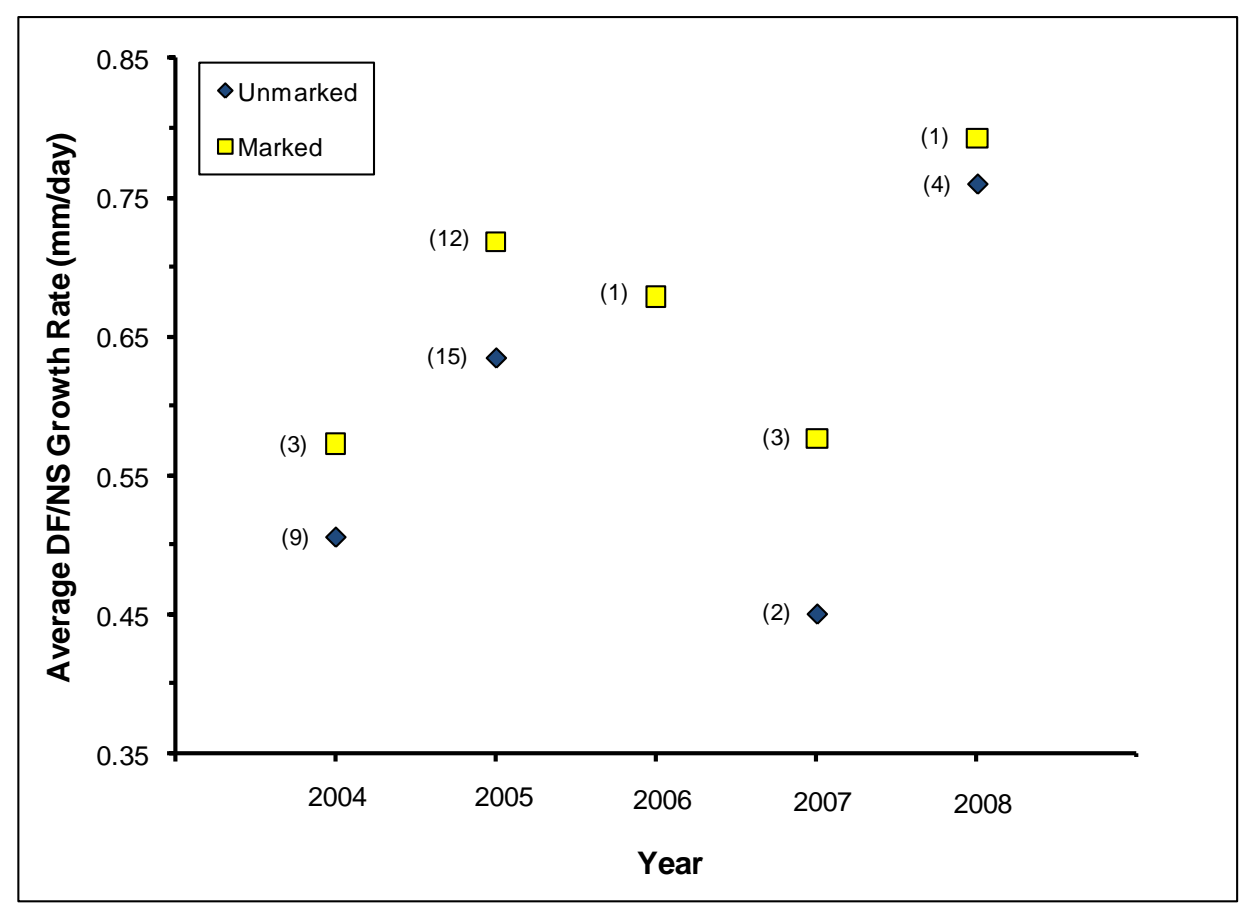

Figure 6. Average delta-flats/nearshore (DF/NS) growth rate ( $\mathrm{mm} /$ day) by year for unmarked and marked juvenile Chinook salmon collected from the delta-flats (DF) and nearshore (NS) habitats, Nisqually River Basin, Washington, 2004-08. Sample size (n) is represented in parentheses. 


\section{Unmarked Juvenile Chinook}

The TDCK was first observed on unmarked Chinook collected in mid-April from DF habitat and mid-May from NS habitat (fig. 7). The DFCK was visible on Chinook collected from the DF habitat beginning in early March $(n=1)$ and from the NS habitat beginning in mid-March ( $n=1)$ (fig. 8). The presence or absence of a DFCK in the DF and NS habitats from early February through early July for unmarked Chinook is represented in figure 9. In a subset of unmarked Chinook collected in the DF and NS habitats early in the season (early February through mid-April, 10 out of 32), we observed FW residence followed directly by a DFCK and DF/NS residence indicating the presence of a fry migrant life history (fig. 10). These particular Chinook reside in the FW habitat for an extremely short period after emergence, quickly migrate downstream, bypassing the tidal delta habitat, and then move directly into the DF and NS habitats. No fry migrant life history was observed on otoliths collected in 2004 and 2006.

Differences in MIW and complete tidal delta and DF/NS growth rates were tested for between DF and NS habitats. The one-way ANOVA showed no significant difference between habitats in DF/NS MIW ( $\mathrm{P} \geq 0.724)$ or in complete tidal delta $(\mathrm{P} \geq 0.748)$ and $\mathrm{DF} / \mathrm{NS}(\mathrm{P} \geq 0.96)$ growth rates, therefore the data from the DF and NS habitats were combined. With samples analyzed from multiple years within the DF and NS habitats, a one-way ANOVA was additionally run to test for differences between years. There was no significant difference $(\mathrm{P} \geq 0.245, \mathrm{n}=21)$ between years among $\mathrm{DF} / \mathrm{NS}$ MIW. However, there was a significant difference among years for complete tidal delta $(\mathrm{P} \leq 0.0316, \mathrm{n}=21)$ and $\mathrm{DF} / \mathrm{NS}$ growth rates $(\mathrm{P} \leq 0.0004, \mathrm{n}=30)$.

On average, the MIW of the FW portion on all unmarked otolith samples was smallest followed by the tidal delta and the DF/NS portions, respectively, regardless of the year (fig. 4). The average complete tidal delta growth rate was the highest in 2008 (mean=0.56 mm/day) followed by 2005 (mean=0.52 mm/day) and then followed by 2004 and 2007 which were the same (mean=0.41 $\mathrm{mm} /$ day) (fig. 5). The average DF/NS growth rate in 2008 (mean=0.76 mm/d, $\mathrm{n}=4$ ) was the highest followed by 2005 (mean=0.63 mm/d, n=15), 2004 (mean=0.51 mm/d, n=9), and 2007 (mean=0.45 mm/d, n=2) (fig. 6). No unmarked DF samples were collected in 2006 and samples collected in the NS during this year did not display a DFCK as the majority of the samples (14 of 19) were caught early in the season, immediately upon NS arrival. Furthermore, no differences were observed in average MIW and growth rates across sampling months for Chinook residing in the DF and NS habitats.

We tested for differences in residence time and fork length at entrance to and exit from the tidal delta between DF and NS habitats. A one-way ANOVA showed a significant difference between years $(\mathrm{P} \leq 0.0064)$ and habitats $(\mathrm{P} \leq 0.0308)$ in fork length at entrance to the tidal delta habitat, so the data were separated by year and habitat (table 5). We detected no significant difference, however, between years $(\mathrm{P} \geq 0.563)$ or habitat $(\mathrm{P} \geq 0.523)$ in fork length at exit from the tidal delta habitat; therefore, the data for fork length at exit from the tidal delta habitat were combined. Likewise, there was no significant difference $(\mathrm{P} \geq 0.450)$ between years for fork length at entry to the DF and NS habitats for fry migrants, so the data for all years was combined. A significant difference $(\mathrm{P} \leq 0.049)$ existed between years in complete tidal delta residence time, thus the residence time data was separated by year. 


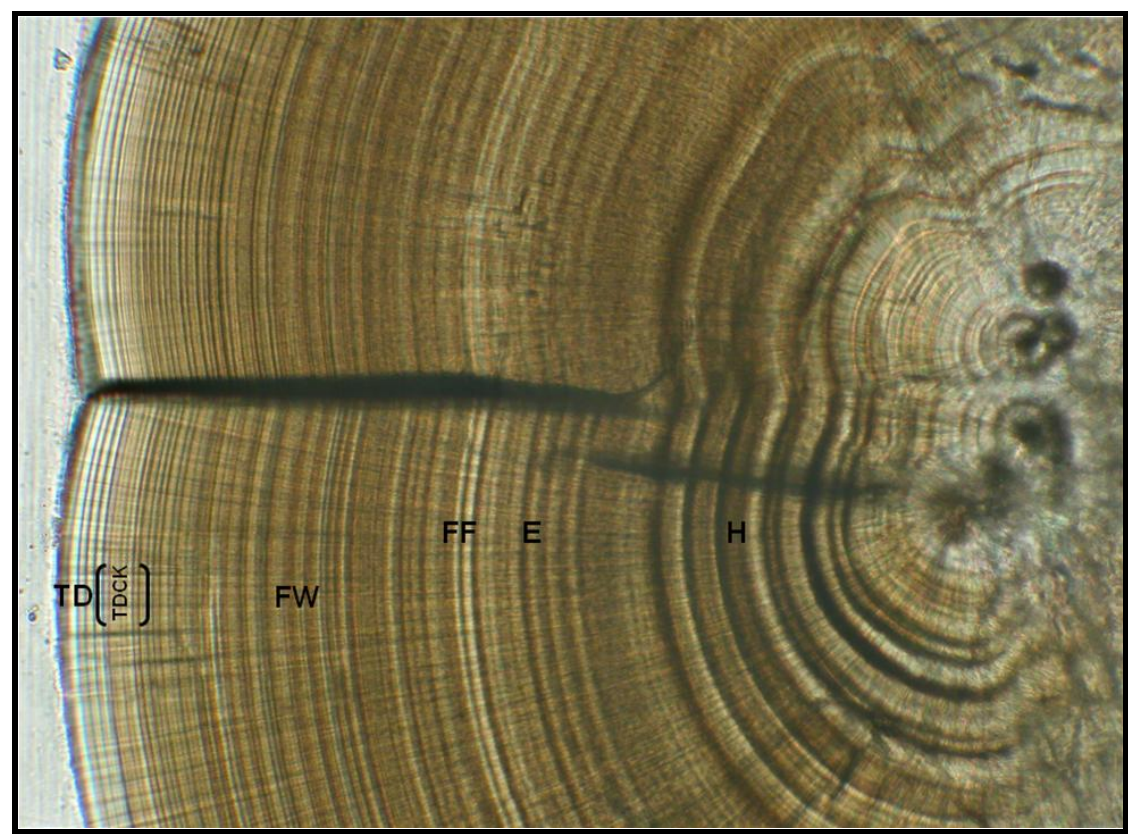

20x objective

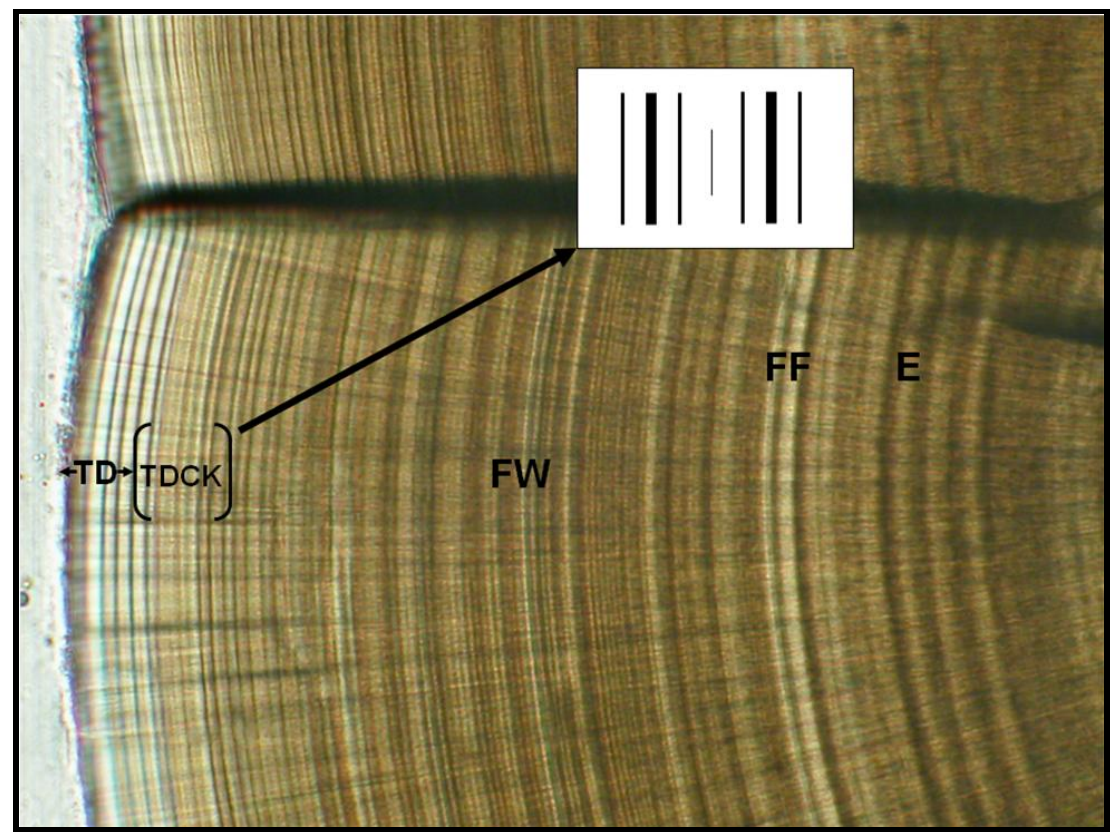

40x objective

Figure 7. Representative otolith sample depicting the tidal delta check (TDCK) as seen on unmarked juvenile Chinook salmon collected in the delta-flats (DF) habitat beginning in mid-April 2004-08 and in the nearshore (NS) habitat beginning in mid-May 2004-08, Nisqually River Basin, Washington. The check was bold and prominent, consisting of two thin dark bands encompassing two wide bright bands containing a thick dark band between them. This sequence was repeated after approximately one increment. Beyond the TDCK, increments were consistently wider, indicating increased growth. Abbreviations: $\mathrm{H}=$ hatch, $\mathrm{E}=$ emergence, $\mathrm{FF}=$ first feed, $\mathrm{FW}=$ freshwater residence, TDCK = tidal delta check, and $\mathrm{TD}=$ tidal delta residence. 


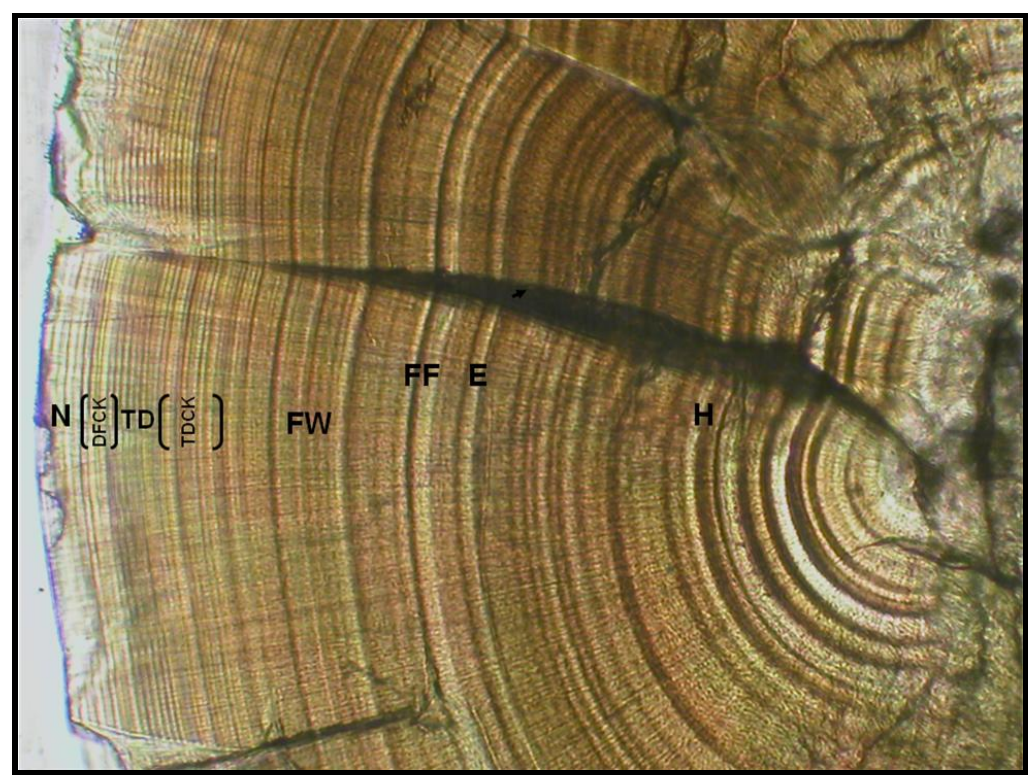

20x objective

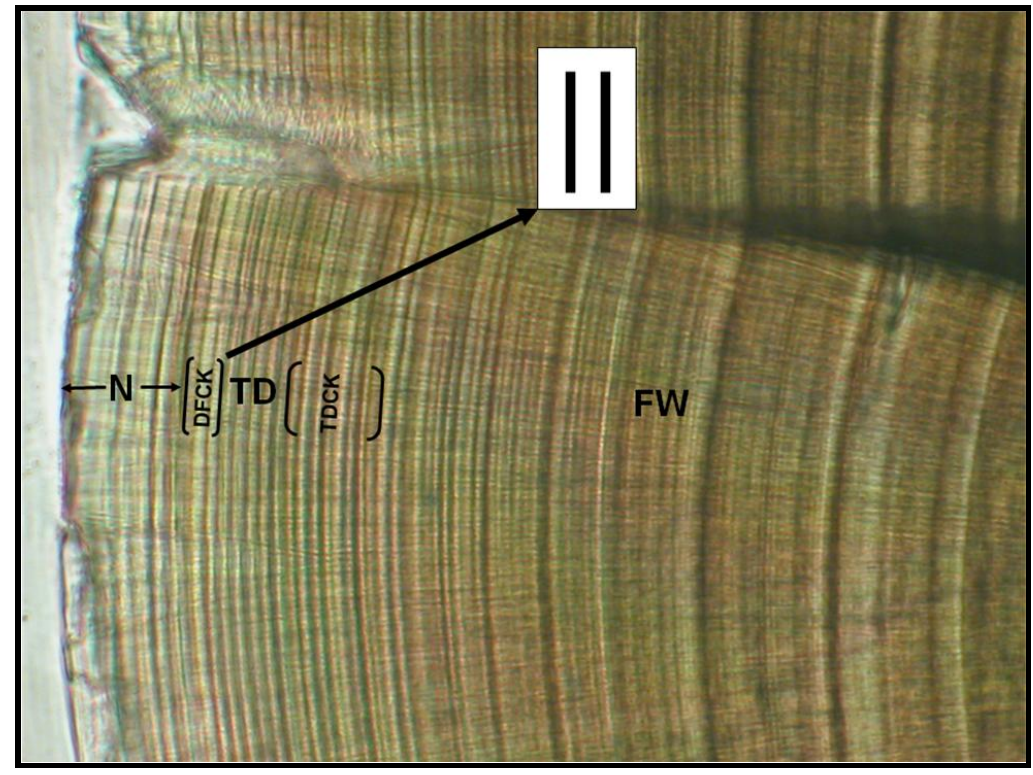

40x objective

Figure 8. Representative otolith sample depicting the delta-flats check (DFCK) as seen on unmarked juvenile Chinook salmon collected in the delta-flats (DF) habitat beginning in early March 2004-08 and in the nearshore (NS) habitat beginning in mid-March 2004-08, Nisqually River Basin, Washington. The check was bold and prominent, consisting of two wide dark bands with a wide bright band in between. The DFCK looked similar in samples from 2004-08, except in 2004 the check contained a thick dark band between the two wide dark bands. Beyond the DFCK, increments were consistently wider, indicating increased growth. Abbreviations: $\mathrm{H}=$ hatch, $\mathrm{E}=$ emergence, $\mathrm{FF}=$ first feed, $\mathrm{FW}=$ freshwater residence, $\mathrm{TDCK}=$ tidal delta check, $\mathrm{TD}=$ tidal delta residence, DFCK = delta-flats check, and $\mathrm{N}=$ delta-flats/nearshore residence. 


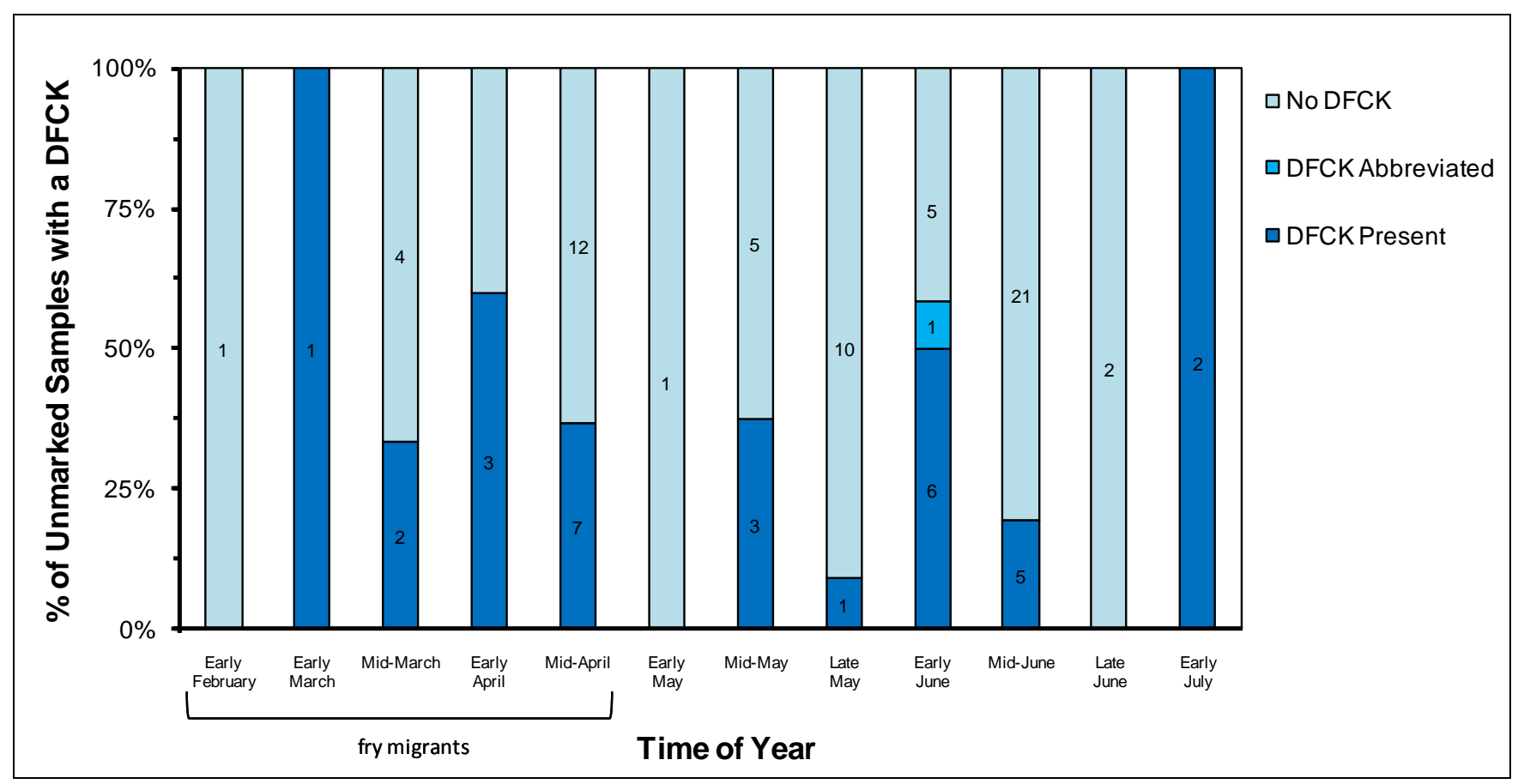

Figure 9. Presence or absence of a delta-flats check (DFCK) on unmarked juvenile Chinook salmon collected in the delta-flats (DF) and nearshore (NS) habitats, Nisqually River Basin, Washington, 2004-08. The term "fry migrants" represents potential time of the year for fry to bypass the tidal delta ( $n=10$ out of 32 ). 


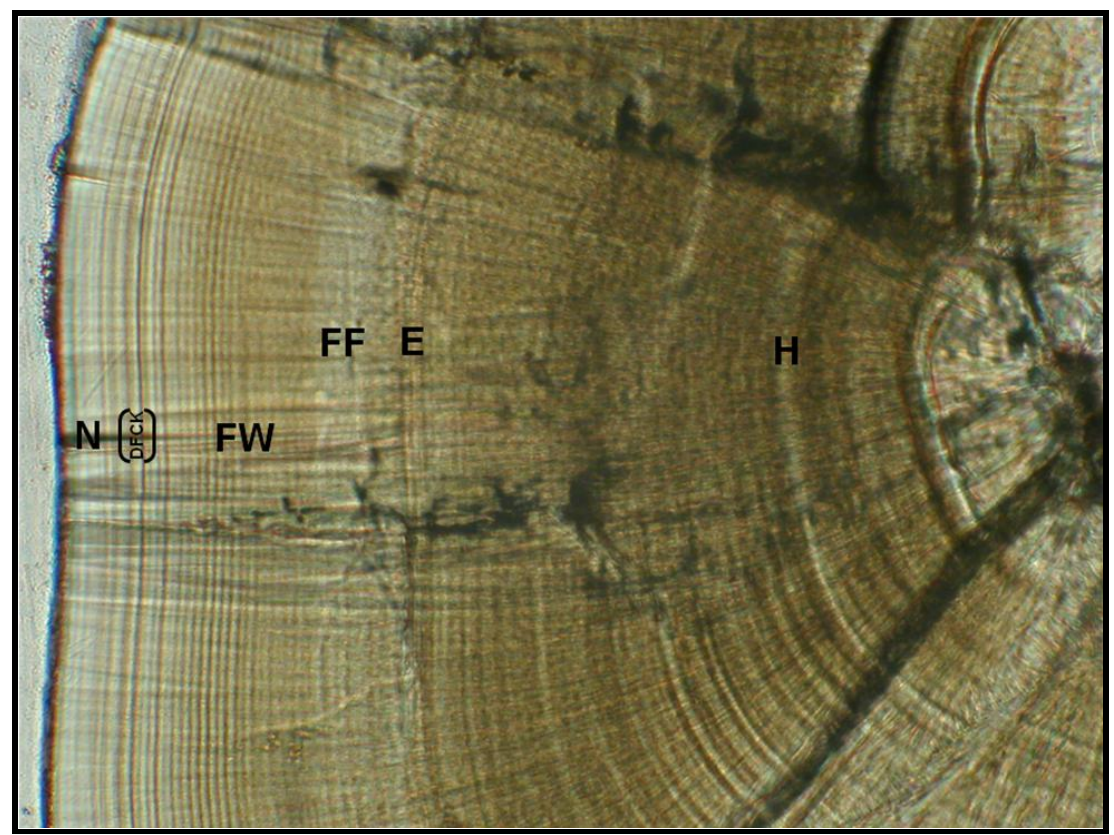

20x objective

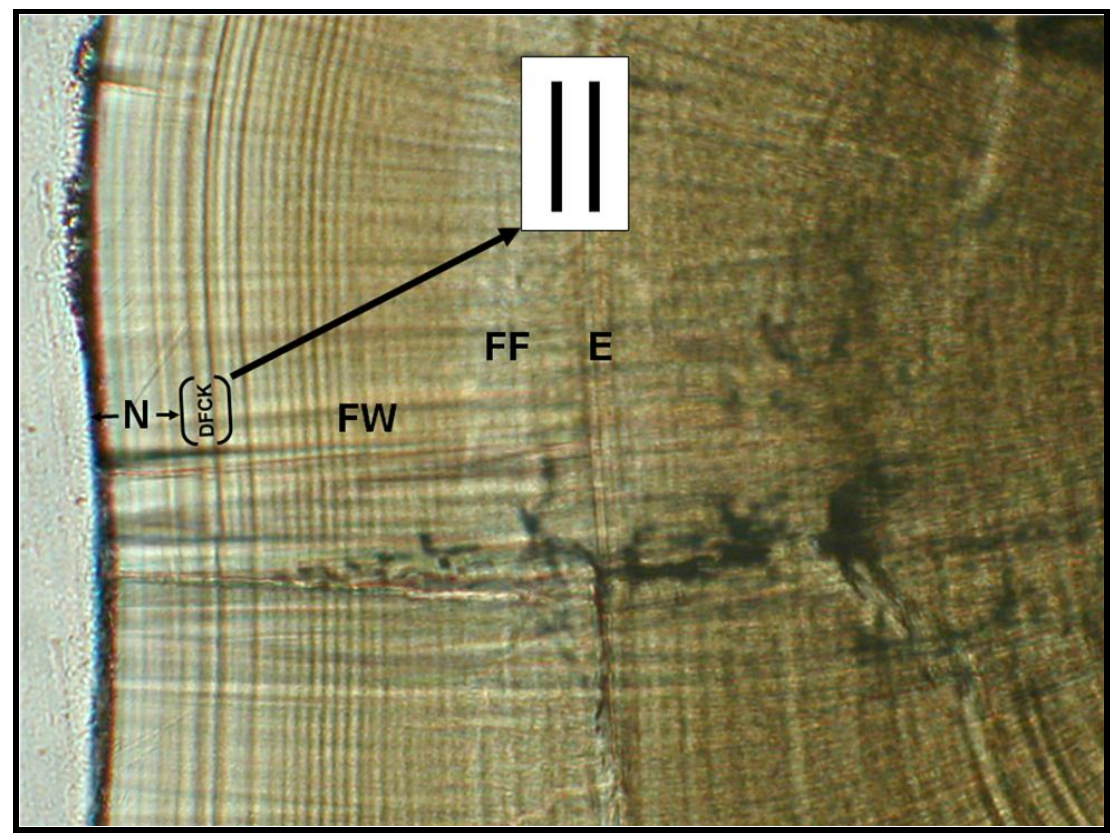

40x objective

Figure 10. Representative otolith sample of fry migrants seen on unmarked juvenile Chinook salmon collected in the delta-flats (DF) habitat beginning in early February and the nearshore (NS) habitat in mid-March 2005 and 2007-08, Nisqually River Basin, Washington. The otolith microstructure of these fish displayed freshwater (FW) residence followed directly by a delta-flats check (DFCK) and delta-flats/nearshore (DF/NS) residence.

Abbreviations: $\mathrm{H}=$ hatch, $\mathrm{E}=$ emergence, $\mathrm{FF}=$ first feed, $\mathrm{FW}=$ freshwater residence, $\mathrm{DFCK}=$ delta-flats check, and $\mathrm{N}=\mathrm{DF} / \mathrm{NS}$ residence. 
Table 5. Average fork length (in millimeters) of unmarked juvenile Chinook salmon at entrance to and exit from the tidal delta, separated by year and habitat type, Nisqually River Basin, Washington, 2004-08.

[Results for 2007 represent small and different sample sizes based on the presence and absence of a delta-flats check (DFCK), resulting in a fork length smaller upon exit than entrance]

\begin{tabular}{|c|c|c|c|}
\hline \multirow[b]{2}{*}{ Year } & & \multicolumn{2}{|c|}{ Habitat Type } \\
\hline & & $\begin{array}{l}\text { Delta- } \\
\text { flats } \\
\text { (DF) }\end{array}$ & $\begin{array}{c}\text { Nearshore } \\
\text { (NS) }\end{array}$ \\
\hline \multirow[t]{2}{*}{2004} & Average Fork Length at Entry to Tidal Delta (mm) & 61.66 & 60.16 \\
\hline & Average Fork Length at Exit from Tidal Delta (mm) & 70.08 & \\
\hline \multirow[t]{2}{*}{2005} & Average Fork Length at Entry to Tidal Delta (mm) & 72.99 & 74.44 \\
\hline & Average Fork Length at Exit from Tidal Delta (mm) & 76.08 & 86.28 \\
\hline \multirow[t]{2}{*}{2006} & Average Fork Length at Entry to Tidal Delta (mm) & & 75.56 \\
\hline & Average Fork Length at Exit from Tidal Delta (mm) & & \\
\hline \multirow[t]{2}{*}{2007} & Average Fork Length at Entry to Tidal Delta (mm) & & $78.30(n=3)$ \\
\hline & Average Fork Length at Exit from Tidal Delta (mm) & & $72.21(\mathrm{n}=1)$ \\
\hline \multirow[t]{2}{*}{2008} & Average Fork Length at Entry to Tidal Delta (mm) & 65.51 & 72.11 \\
\hline & Average Fork Length at Exit from Tidal Delta (mm) & 79.41 & \\
\hline \multirow[t]{2}{*}{ 2004-2008 } & Average Fork Length at Entry to Tidal Delta (mm) & 66.79 & 74.30 \\
\hline & Average Fork Length at Exit from Tidal Delta (mm) & 73.59 & 79.24 \\
\hline
\end{tabular}

The average length of Chinook salmon caught in the DF and NS habitats upon exit from the tidal delta was $74.1 \mathrm{~mm}(\mathrm{n}=21)$. Fry migrants collected in the DF and NS habitats early in the season (early February to mid-April) were, on average, $41.3 \mathrm{~mm}$ when they entered the DF and NS habitats. Unmarked Chinook resided longer in the tidal delta in 2004 (on average 22 days, $n=9$ ) than in 2005 (15 days, $n=9$ ), 2007 (12 days, $n=1$ ), and 2008 (11 days, $n=2$ ) (fig. 11). Even though sample sizes were very small in 2007 and 2008, the average residence time in the tidal delta habitat for those years falls within the range of residence time seen in 2004 (10-35 days) and 2005 (8-22 days). No samples displayed a DFCK in 2006 therefore a complete average residence time did not exist for that year. 


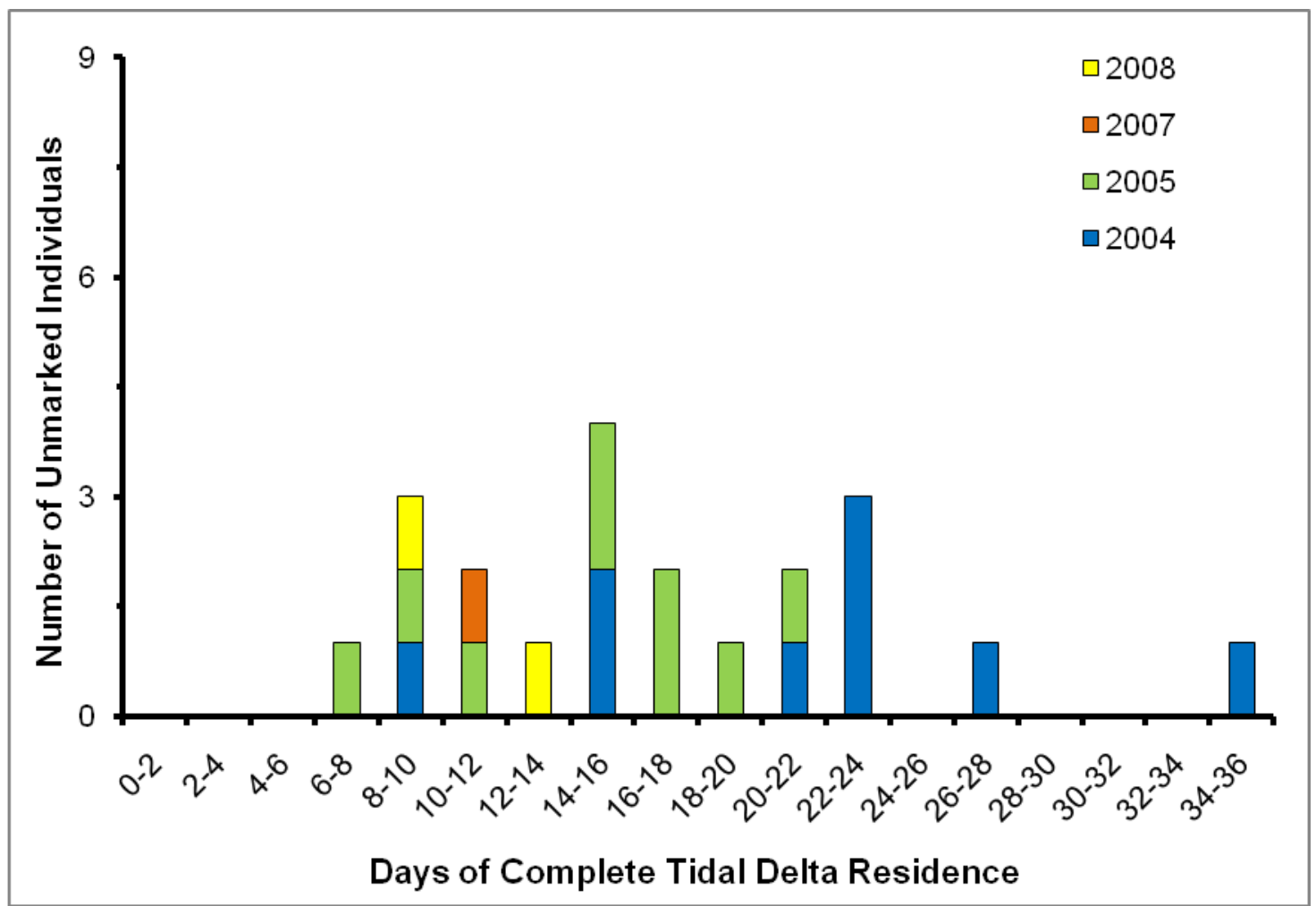

Figure 11. Complete tidal delta residence time (days), separated by year, for individual unmarked juvenile Chinook salmon caught in the delta-flats (DF) and nearshore (NS) habitats, Nisqually River Basin, Washington, 2004-08. No samples in 2006 displayed a delta-flats check (DFCK).

\section{Marked Juvenile Chinook}

The TDCK was first observed on otoliths of marked juvenile Chinook collected in mid-May from the DF habitat and early May from the NS habitat (fig. 12). The DFCK was visible on otoliths of fish collected from the DF habitat in mid-May and the NS habitat beginning in late May (fig. 13). Presence of a check earlier in the season (prior to May) is not applicable because the fish are still residing in the hatchery at that time. The presence or absence of a DFCK in the DF and NS habitats from early May through early August for marked samples is represented in figure 14.

Differences in MIW and complete tidal delta and DF/NS growth rates were tested between DF and NS habitats. The one-way ANOVA showed no significant difference in MIW ( $\mathrm{P} \geq 0.34)$ or complete tidal delta $(\mathrm{P} \geq 0.976)$ and $\mathrm{DF} / \mathrm{NS}(\mathrm{P} \geq 0.47)$ growth rates, therefore the data from the DF and NS habitats was combined. With samples analyzed from multiple years in the DF and NS habitats, a one-way ANOVA was additionally run to test for differences between years. There was no significant difference $(\mathrm{P} \geq 0.35, \mathrm{n}=16)$ between years among DF/NS MIW. However, there was a significant difference among years for complete tidal delta $(\mathrm{P} \geq 0.047, \mathrm{n}=21)$ and $\mathrm{DF} / \mathrm{NS}$ growth rates $(\mathrm{P} \geq 0.016, \mathrm{n}=20)$. 


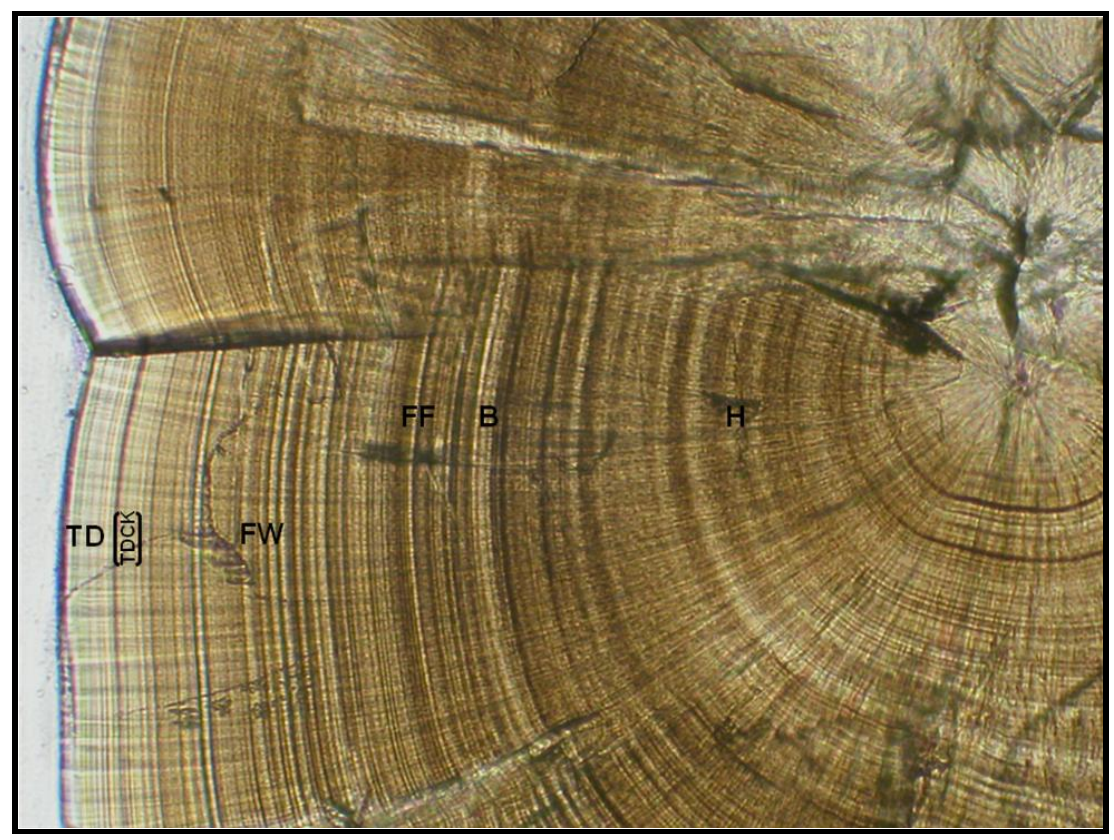

20x objective

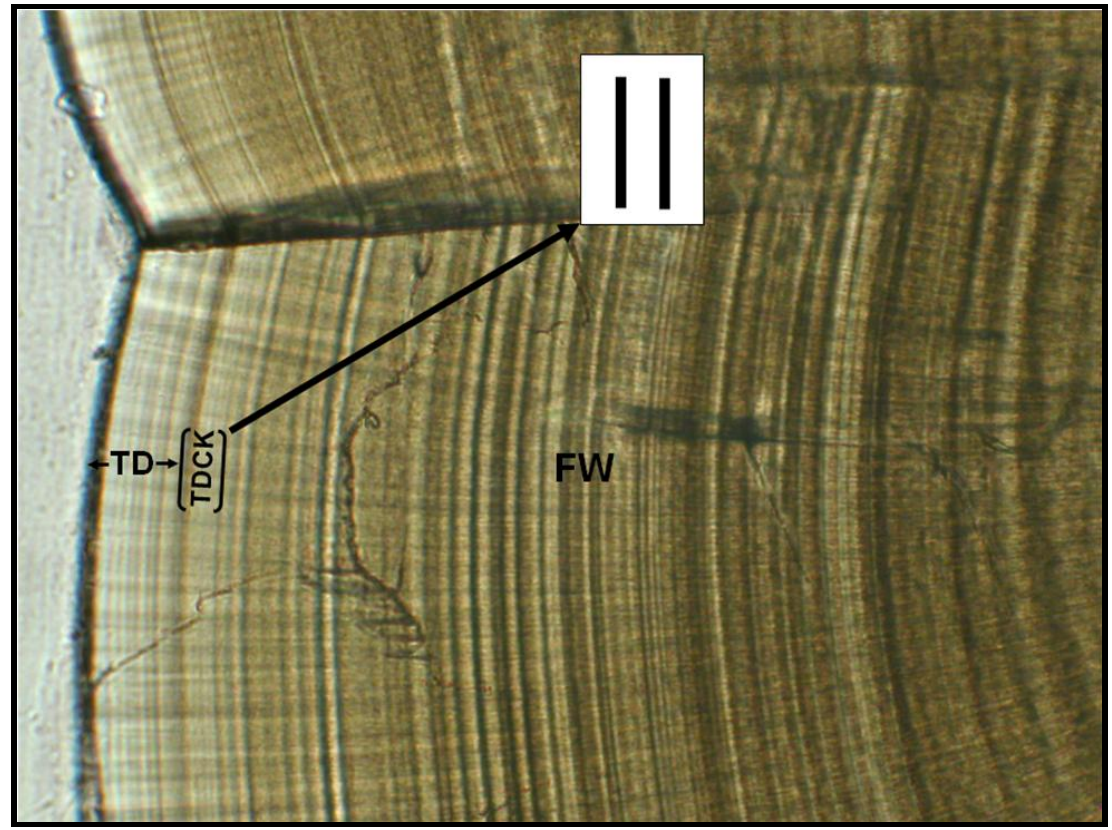

40x objective

Figure 12. Representative otolith sample depicting the tidal delta check (TDCK) as seen on marked juvenile Chinook salmon collected in the delta-flats (DF) habitat beginning in mid-May 2004-08 and in the nearshore (NS) habitat beginning in early May 2004-08, Nisqually River Basin, Washington. The check was bold and prominent, consisting of two thick dark bands with a wider white space between. Beyond the TDCK, increments were consistently wider indicating increased growth. Abbreviations: $\mathrm{H}=$ hatch, $\mathrm{B}=$ button-up, $\mathrm{FF}=$ first feed, $\mathrm{FW}=$ freshwater residence, TDCK = tidal delta check, and TD = tidal delta residence. 


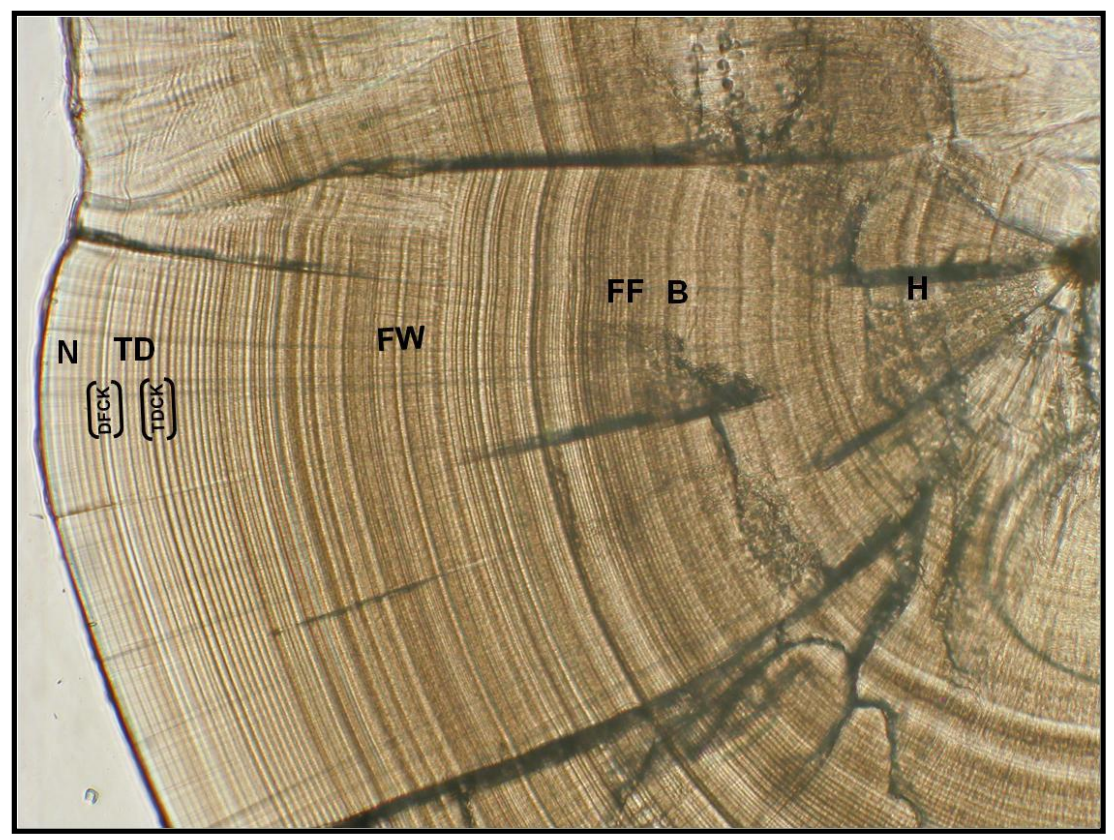

20x objective

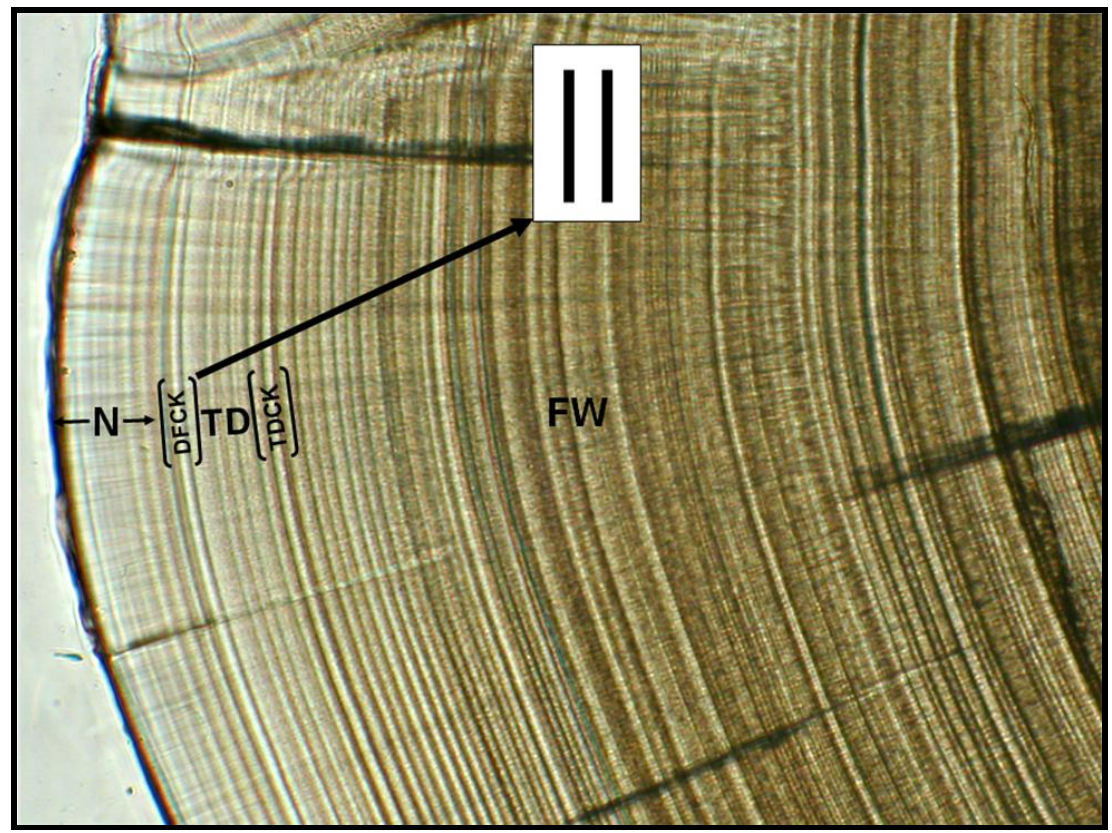

40x objective

Figure 13. Representative otolith sample depicting the delta-flats check (DFCK) as seen on marked juvenile Chinook salmon collected in the delta-flats (DF) habitat beginning in mid-May 2004-08 and in the nearshore (NS) habitat beginning in late May 2004-08, Nisqually River Basin, Washington. The check was bold and prominent, consisting of two wide dark bands with a wide bright band in between. The DFCK looked similar in samples from 2004-08, except in 2004 the check contained a thick dark band between the two wide dark bands. Beyond the DFCK, increments were consistently wider, indicating increased growth. Abbreviations: $H=$ hatch, $B=$ button-up, $\mathrm{FF}=$ first feed, $\mathrm{FW}=$ freshwater residence, $\mathrm{TDCK}=$ tidal delta check, TD = tidal delta residence, $\mathrm{DFCK}=$ delta-flats check, and $\mathrm{N}=$ delta-flats/nearshore residence. 


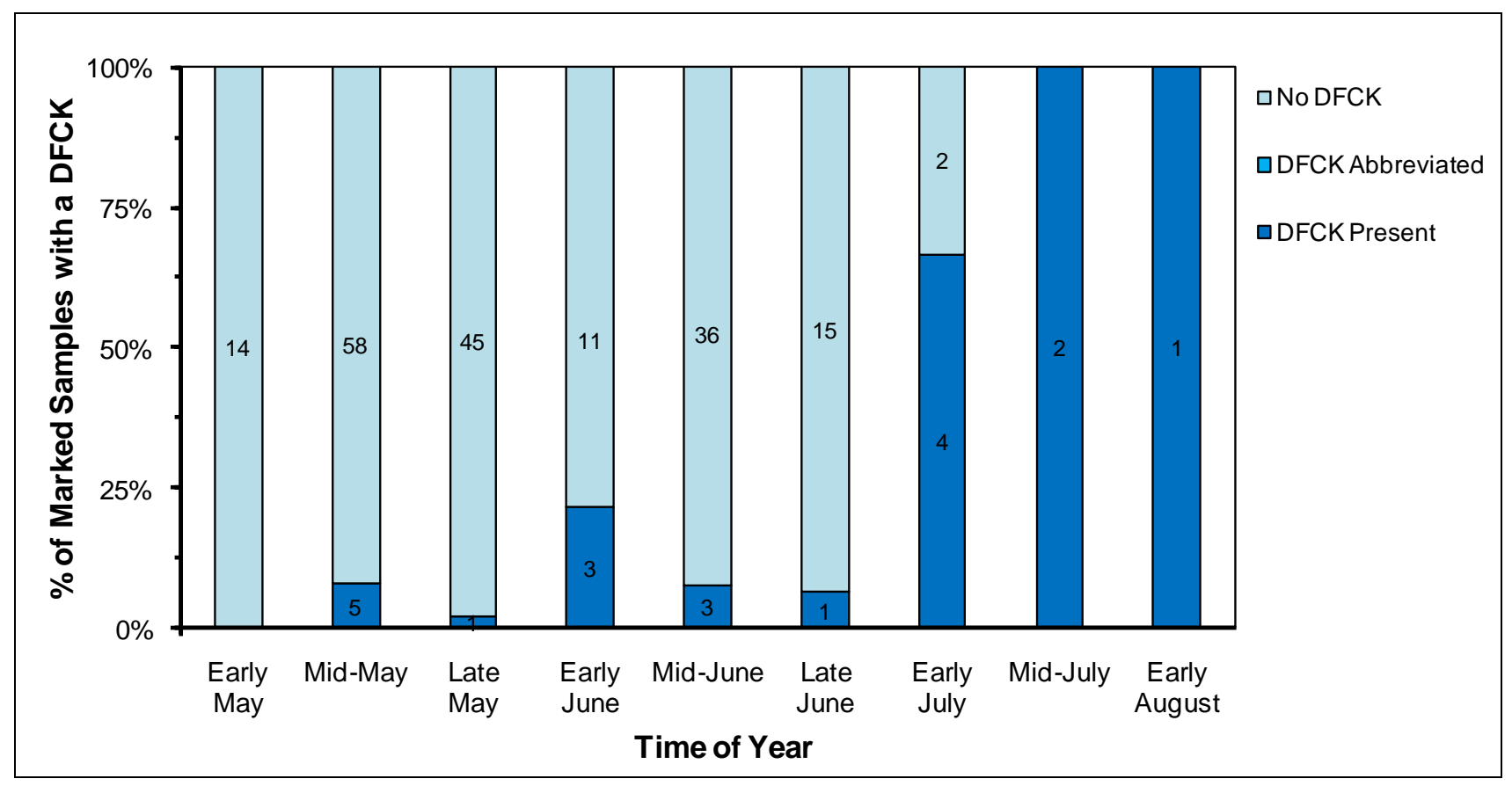

Figure 14. Presence or absence of a delta-flats check (DFCK) on marked juvenile Chinook salmon collected in the delta-flats (DF) and nearshore (NS) habitats, Nisqually River Basin, Washington, 2004-08.

On average, the MIW of the FW portion on all marked Chinook otoliths was smallest followed by the tidal delta and the DF/NS portions, respectively, regardless of the year (fig. 4). Because a release check could not clearly be identified, the FW growth included for analysis represents time spent in the hatchery prior to release and time spent in the river after hatchery release. The average complete tidal delta growth rate in the year $2008(0.67 \mathrm{~mm} / \mathrm{d}, \mathrm{n}=1)$ was the highest followed by $2006(0.62 \mathrm{~mm} / \mathrm{d}$, $\mathrm{n}=1), 2004($ mean $=0.57 \mathrm{~mm} / \mathrm{d}, \mathrm{n}=3), 2005($ mean $=0.56 \mathrm{~mm} / \mathrm{d}, \mathrm{n}=12)$, and $2007($ mean $=0.46 \mathrm{~mm} / \mathrm{d}, \mathrm{n}=3)$ (fig. 5). The average DF/NS growth rate in the year $2008(0.79 \mathrm{~mm} / \mathrm{d}, \mathrm{n}=1)$ was the highest followed by $2005($ mean $=0.72 \mathrm{~mm} / \mathrm{d}, \mathrm{n}=12), 2006(0.68 \mathrm{~mm} / \mathrm{d}, \mathrm{n}=1), 2007($ mean=0.58 mm/d, $\mathrm{n}=3)$, and 2004 (mean=0.57 mm/d, $\mathrm{n}=3$ ) (fig. 6).

We tested for differences in residence time and fork length at entrance to and exit from the tidal delta between DF and NS habitats. The one-way ANOVA showed no significant difference in fork lengths at entry to $(\mathrm{P} \geq 0.707)$ or exit from $(\mathrm{P} \geq 0.467)$ the tidal delta; therefore, the data between habitats was combined. We then tested for differences between years in residence time and fork lengths at entrance to and exit from the tidal delta. A one-way ANOVA showed no significant difference $(\mathrm{P} \geq 0.3103)$ between years in fork lengths at entrance to and exit from the tidal delta habitat $(\mathrm{P} \geq 0.0614)$, therefore the data between years was combined. A significant difference $(\mathrm{P} \leq 0.005)$ existed between years in complete residence time therefore the residence time data was separated by year.

Marked fish caught in the DF and NS habitats for all sampling years combined had an average fork length of $86.1 \mathrm{~mm}(\mathrm{n}=82)$ upon entry to the tidal delta (table 6). Fish displaying both a TDCK and DFCK ( $\mathrm{n}=20$ of 82 ) had an average fork length of $81.9 \mathrm{~mm}$ at tidal delta entry and $86.1 \mathrm{~mm}$ upon tidal delta exit. Marked fish spent longer in the tidal delta in 2007 (on average 20 days, $n=3$ ) than in the years 2004 ( 7 days, $n=3$ ), 2005 ( 7 days, $n=12$ ), 2006 ( 6 days, $n=1$ ), and 2008 ( 4 days, $n=1$ ) (fig. 15). Even though the sample sizes were small in 2004, 2006, 2007, and 2008, the average tidal delta residence for those years falls within the range in 2005 (2-13 days), except for 2007 when one of the three fish resided in the tidal delta habitat for 30 days. 
Table 6. Average fork length (in millimeters) of marked juvenile Chinook salmon at entrance to and exit from the tidal delta, separated by year, Nisqually River Basin, Washington, 2004-08.

[Results for 2004, 2007, and 2004-08 represent small and different sample sizes based on the presence and absence of a delta-flats check (DFCK), resulting in a fork length smaller upon exit than entrance]

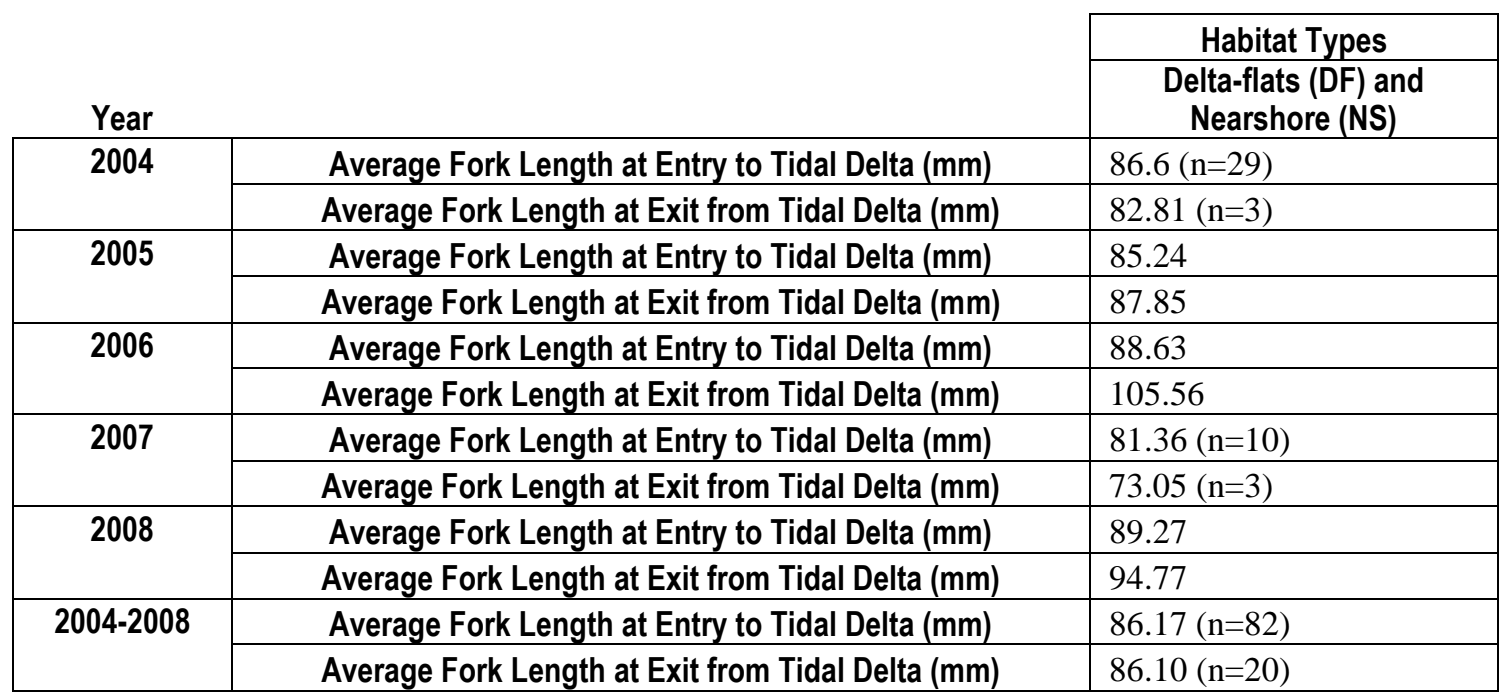

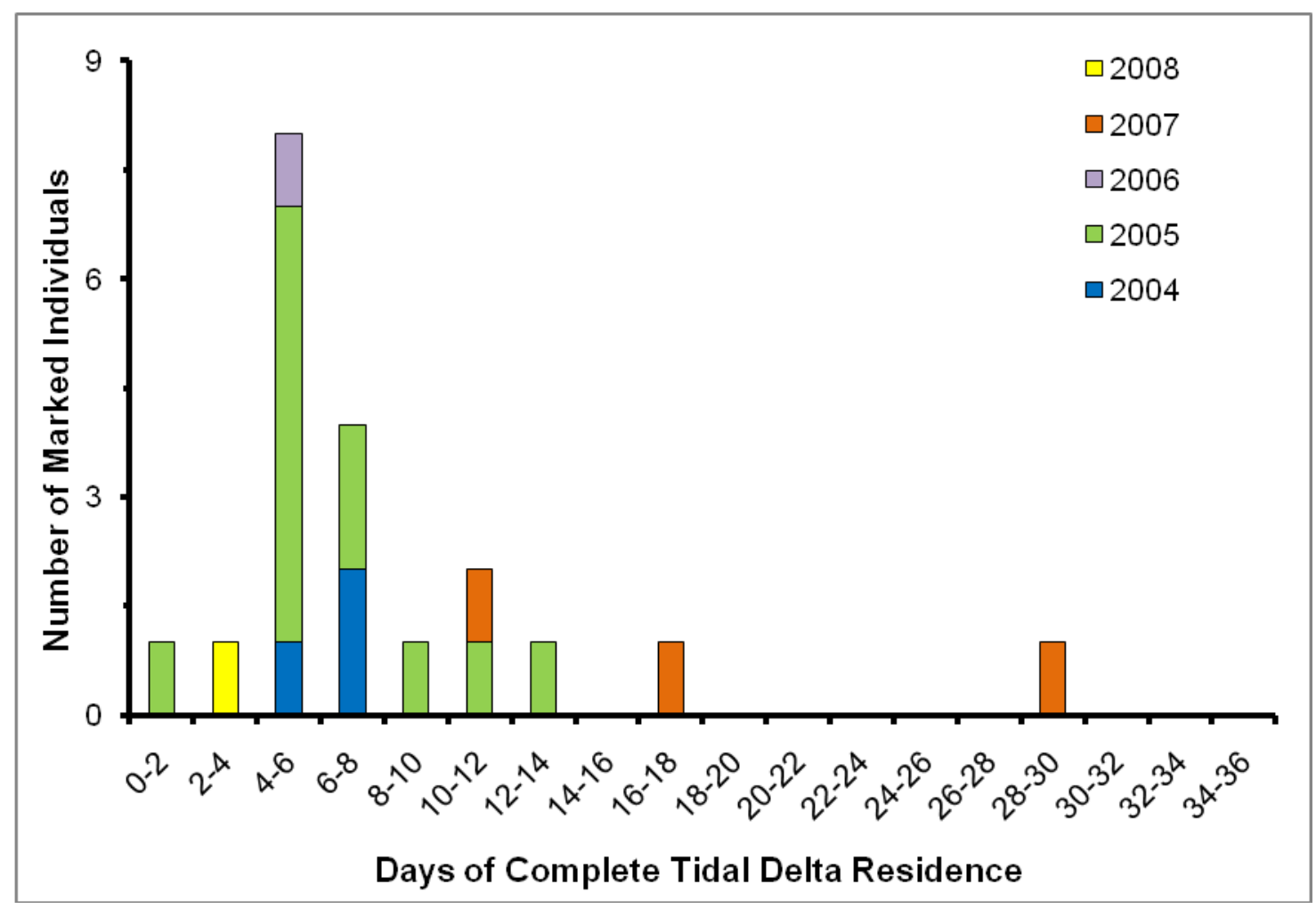

Figure 15. Complete tidal delta residence time (days), separated by year, for individual marked juvenile Chinook salmon caught in the delta-flats (DF) and nearshore (NS) habitats, Nisqually River Basin, Washington, 2004-08. 


\section{Discussion}

Hatchery Chinook salmon outnumber wild Chinook in the Nisqually River (Ellings and Hodgson, 2007); however distinct microstructural otolith patterns unique to fish from the Clear Creek and Kalama hatcheries allowed us to recognize and separate the collection into unmarked hatchery and wild fish. A check associated with the release of marked fish from the two hatcheries on marked samples could not be identified possibly due to volitional releases. Collection of additional samples directly from the hatchery prior to ponding may help us to identify a release check. The presence of a release check will allow us to determine how quickly hatchery fish move to the tidal delta and estimate FW growth in the river following release.

As with the 2004 (marked and unmarked) and 2005 (unmarked) collection, we were able to characterize a Nisqually-specific signature of otolith microstructural growth patterns and checks for juvenile Chinook, which allowed us to distinguish entry into the DF and NS habitats. The appearance of the DFCK on unmarked and marked Chinook samples collected in 2005-08 varied slightly from that seen on samples previously analyzed from 2004. The DFCK looked similar except for one fewer increment in 2004; therefore, no sign of inter-annual variation in check appearance was recorded. The presence or absence of checks was observed on samples throughout the migration season, but did not vary from that seen in 2004 (unmarked and marked) and 2005 (unmarked) collections. We conclude that these results are not reflective of the otoliths deposition rate of expression or incorporation to changes in environmental conditions. Rather, the results can be explained by the movement of cohorts into and out of specific habitats as it relates to time of catch. Previous analysis of fish collected in the tidal delta habitat has shown the same pattern of check deposition (Lind-Null and Larsen, 2009). Furthermore, presence or absence of checks cannot be explained by temperature due to the presence of the DFCK seen on fry migrants collected in the DF and NS habitats early in the season (February-mid April) when water temperatures are cooler.

A fry migrant life history was observed on otoliths of unmarked Chinook collected in 2005, 2007, and 2008. Samples collected in the PE may be of interest to analyze to determine if these samples are fry migrants based on time of collection.

Complete tidal delta residence time and size at exit, and DF/NS growth rates and MIW have been minimally documented in past reports (Lind-Null and others, 2008a, 2008b; Lind-Null and Larsen, 2009) due to small sample sizes. Complete tidal delta growth rates have never been documented due to low sample sizes in the past. Our goal for this report was to combine data for multiple sampling years to increase sample sizes in the DF and NS habitats. However, we found a significant difference between years in growth rates, residence time, and fork length at entrance to the tidal delta. In addition, the number of samples that displayed a DFCK remained low due to the lack of Chinook caught later in the season (July-October) when the check is more prevalent (figs. 9 and 14). Therefore, we were not able to combine the data for some variables and once again, in some instances, are left with small sample sizes for a given year.

Mean increment widths increased as the unmarked and marked Chinook moved from FW to the DF and NS habitats. Generally, FW MIW of unmarked fish, on average, was smaller than marked Chinook, followed by tidal delta and DF/NS portions respectively. The average complete tidal delta and $\mathrm{DF} / \mathrm{NS}$ growth rates for unmarked Chinook were consistently lower compared to marked Chinook during all years; however, sample size was small during some years. The complete tidal delta and DF/NS growth rates were highest for unmarked and marked Chinook during 2008 compared to all other sampling years. The complete tidal delta growth rate for unmarked and marked Chinook was consistently lower than the DF/NS growth rate for all sampling years. Unmarked and marked Chinook 
displayed a similar trend in between year differences for complete tidal delta and DF/NS growth rates. Unmarked Chinook, on average, spent longer in the tidal delta compared to marked Chinook.

Our results from this study indicate that otolith microstructural analysis can be a valuable tool in establishing baseline information regarding the utilization of Nisqually River estuary habitats by juvenile Chinook salmon prior to restoration efforts. Restoration may provide additional rearing habitat favorable to juvenile Chinook that may be reflected on the otoliths through higher growth rates and longer residence times.

However, collection and analysis of additional unmarked and marked Chinook in the DF and NS habitat zones later in the season (July-October) should be addressed. In addition, analysis of otolith microchemistry in conjunction with microstructure may provide an additional tool for validating our microstructure findings related to habitat entry. Currently, we are working on analyzing adult Chinook otoliths from brood year 2003 to examine the proportions and numbers of juveniles that reared in the estuary and successfully returned to spawn.

\section{Acknowledgments}

This research was a collaborative effort between the Nisqually Indian Tribe and the U.S. Geological Survey, Western Fisheries Research Center. A special thanks to Karl Stenberg, Sayre Hodgson, Chris Ellings, Jeanette Dorner, Jean Takekawa, Marian Bailey, Jennifer Cutler, Nano Perez, Craig Smith, John Kerwin, NNWR volunteers, and WDFW staff at Lakewood/Garrison Springs, Clear Creek, Kalama, Tumwater Falls Acclimation Pond, Hupp Springs, Minter Creek, Soos Creek, Voights Creek, White River, and Clark's Creek Hatcheries, including Jim Jenkins, Bill St. Jean, Mary Evans, John Lovrak, Wayne Tran, Sherman Davis, Richard Johnson, and Blake Smith.

\section{References Cited}

Beamer, E.M., and Larsen, K.A., 2004, The importance of Skagit Delta habitat on the growth of wild ocean-type Chinook in Skagit Bay - Implications for delta restoration: Skagit River System Cooperative, 6 p., accessed March 31, 2009, at http://www.skagitcoop.org/index.php/documents/.

Bottom, D.L., Jones, K.K., Cornwell, T.J., Gray, A., and Simenstad, C.A., 2005, Patterns of Chinook salmon migration and residency in the Salmon River estuary (Oregon): Estuarine, Coastal and Shelf Sciences, v. 64, p. 79-93.

Brothers, E.B., 1990, Otolith Marking: American Fisheries Society Symposium, v. 7, p. 183-202.

Campana, S.E. 1983, Calcium deposition and otolith check formation during periods of stress in coho salmon, Oncorhynchus kisutch: Comparative Biochemistry and Physiology, v. 75A, p. 215-220.

Campana, S.E., and Jones, C.M., 1992, Analysis of otolith microstructure data, in Stevenson, D.K., and Campana, S.E., eds., Otolith microstructure examination and analysis: Canadian Special Publication of Fisheries and Aquatic Sciences, v. 117, p. 73-100.

Cowardin, L.M., Carter, V., Golet, F.C., and LaRoe, E.T., 1979, Classification of wetlands and deepwater habitat of the United States: Washington, D.C., U.S. Department of the Interior, Fish and Wildlife Service, 79 p.

DeVries, D.R. and Frie, R.V., 1996, Determination of age and growth, in Murphy, B.R., and Willis, D.W., eds., Fisheries techniques (2d ed.): Bethesda, Md, American Fisheries Society, p. 483-512.

Ellings, C.S., and Hodgson, S, 2007, Nisqually estuary baseline fish ecology study: 2003-2006:

Olympia, WA, Nisqually National Wildlife Refuge and Nisqually Indian Tribe, 96 p.

Healey, M.C., 1980, Utilization of the Nanaimo River estuary by juvenile Chinook salmon, Oncorhynchus tshawytsch: Fisheries Bulletin, v. 77, p. 653-668. 
Healey, M.C., 1991, Life history of Chinook salmon (Oncorhynchus tshawytscha), in Groot, C., and Margolis, L., eds., Pacific salmon life histories: Vancouver, BC, University of British Columbia Press, p. 313-393.

Lind-Null, A., Larsen, K., and Reisenbichler, R., 2008a, Pre-restoration habitat use by Chinook Salmon in the Nisqually estuary using otolith analysis: U.S. Geological Survey Open-File Report 2008-1021, $13 \mathrm{p}$.

Lind-Null, A., Larsen, K., and Reisenbichler, R., 2008b, Characterization of estuary use by Nisqually hatchery Chinook based on otolith analysis: U.S. Geological Survey Open-File Report 2008-1102, $12 \mathrm{p}$.

Lind-Null, A., and Larsen, K., 2009, Pre-restoration habitat use by Chinook salmon in the Nisqually estuary using otolith analysis: An additional year: U.S. Geological Survey Open-File Report 20091106, $18 \mathrm{p}$.

Miller, J.A., and Simenstad, C.A., 1997, A comparative assessment of a natural and created estuarine slough as rearing habitat for juvenile Chinook and Coho salmon: Estuaries, v. 20, p. 792-806.

Nisqually Chinook Recovery Team (NCRT), 2001, Nisqually Chinook Recovery Plan Report.

Neilson, J.D., Geen, G.H., and Bottom, D., 1985, Estuarine growth of juvenile Chinook salmon

(Oncorhynchus tshawytscha) as inferred from otolith microstructure: Canadian Journal of Fisheries and Aquatic Sciences, v. 42, p. 899-908.

Simenstad, C.A., Fresh, K.L., and Salo, E.O., 1982, The role of Puget Sound and Washington coastal estuaries in the life history of Pacific salmon: an unappreciated function, in Kennedy, V.S., ed., Estuarine comparisons: New York, Academic Press, p. 343-364.

Sokal, R.R., and Rohlf, F.J., 1981, Biometry: New York, W.H. Freeman and Company, 859 p.

Stevenson, D.K., and Campana, S.E., eds., 1992, Otolith microstructure examination and analysis: Canadian Special Publication of Fisheries and Aquatic Sciences, v. 117, 126 p.

Volk, E.C., Schroder, S.L., and Grimm, J.L., 1999, Otolith thermal marking: Fisheries Research, v. 43, p. 205-219. 
Publishing support provided by the U.S. Geological Survey

Publishing Network, Tacoma Publishing Service Center

For more information concerning the research in this report, contact the Director, Western Fisheries Research Center

U.S. Geological Survey, 6505 NE 65th Street

Seattle, Washington 98115

http://wfrc.usgs.gov/ 


\section{鸹}

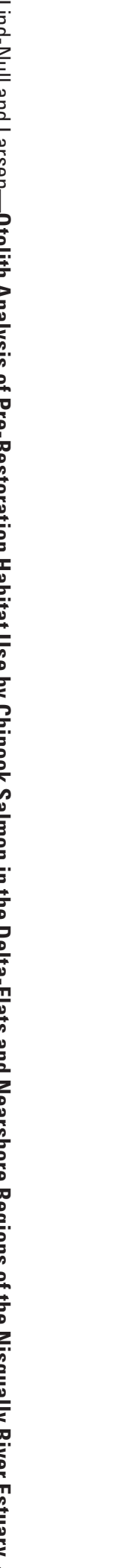

